\title{
Levels and trends of brominated flame retardants in the European environment
}

\author{
Robin J. Law ${ }^{a, *}$, Colin R. Allchin ${ }^{a}$, Jacob de Boer ${ }^{b}$, Adrian Covaci ${ }^{c}$, Dorte Herzke ${ }^{d}$, Peter \\ Lepom $^{\mathrm{e}}$, Steven Morris ${ }^{\mathrm{a}}$, Jacek Tronczynski ${ }^{\mathrm{a}}$ and Cynthia A. de Wit $^{\mathrm{g}}$
}

\author{
${ }^{a}$ The Centre for Environment, Fisheries and Aquaculture Science, CEFAS Burnham Laboratory, \\ Burnham on Crouch, Remembrance Avenue, Essex CM0 8HA, UK \\ ${ }^{\mathrm{b}}$ Netherlands Institute for Fisheries Research (RIVO), P.O. Box 68, IJmuiden, The Netherlands \\ ${ }^{\mathrm{C}}$ Toxicological Centre, University of Antwerp, 2610 Wilrijk, Belgium \\ ${ }^{\mathrm{d}}$ Norwegian Institute for Air Research, The Polar Environmental Centre, N-9296 Tromsø, Norway \\ eUmweltbundesamt, P.O. Box 3300 22, D-14191 Berlin, Germany \\ 'Institut Français de Recherche pour l'Exploitation de la Mer (IFREMER), BP 21105, 44311 Nantes \\ Cedex 03, France \\ ${ }^{9}$ Department of Applied Environmental Science, Stockholm University, SE-106 91 Stockholm, Sweden \\ *: Corresponding author : Tel.: +44 1621 787271; fax: +44 1621 784989; email:r.j.law@cefas.co.uk
}

\begin{abstract}
:
In this paper, we review those data which have recently become available for brominated flame retardants (particularly the brominated diphenyl ethers (BDEs) and hexabromocyclododecane $(\mathrm{HBCD})$ ) in samples from the European environment. Environmental compartments studied comprise the atmosphere, sediments and soils, sewage sludges, and a variety of biological samples and food chains. This is currently a very active research area, and we cite over 70 studies reported in the literature during 2003-04. Findings include that the input of BDEs (especially BDE209) to the Baltic Sea by atmospheric deposition now exceeds that of PCBs by a factor of almost 40 times. Sewage sludge samples from both industrial and background locations show concentrations of BDEs, HBCD and tetrabromobisphenol-A (TBBP-A) that are of a similar order, indicating that the major source is from diffuse leaching from products into wastewater streams from users, households and industries generally. Point-sources from industries using BFRs (e.g. the textile industry) also generate local hotspots. Sediment core studies identified the presence of two of the three PBDE formulations. The penta-mix formulation was clearly present from the beginning of the 1970s, but the deca-mix only appeared in the late 1970s. BDE183, BDE209 and HBCD were detected in peregrine falcons from Sweden and other birds feeding on terrestrial food chains. BDEs are found widely distributed in fish, including those from high mountain lakes in Europe, as a consequence of long-range atmospheric transport and deposition. A temporal trend study in archived freeze-dried mussels from the Seine estuary, France, indicated an exponential increase in BDE concentrations during the period 19821993, which levelled off in 1999 and 2001 and then began to decline after 2002. HBCD was detected in liver and blubber samples from harbour seals and harbour porpoises from the Wadden and North Seas, though very few animals yielded positive values for TBBP-A. There are difficulties in comparing data on $\Sigma B D E$ from studies in which different suites of BDE congeners have been determined, and we suggest a common suite which will allow the study of all three commercial PBDE formulations.
\end{abstract}

Keywords: Brominated flame retardants; Polybrominated diphenyl ethers; Hexabromocyclododecane; Tetrabromobisphenol-A; Europe; Atmosphere; Sediment; Soil; Sewage sludge; Biota 


\section{Introduction}

Two overviews of the levels and trends of brominated flame retardants (BFRs) in environmental samples, including those in Europe, were published during 2002-03 (de Wit, 2002; Law et al., 2003). This paper takes those reviews as a starting point, and provides an overview of information on levels and trends of BFRs in the European environment, published or accepted for publication subsequently. The cut-off date for incorporation of material either published or available via journal websites was the $30^{\text {th }}$ September 2004.

Recently, Prevedouros et al. (2004) have derived an inventory for the use and atmospheric emissions of the penta-mix polybrominated diphenyl ether (PBDE) formulation in Europe for the period 1970-2000. They estimated that 3,000 to 5,000 tonnes of the penta-mix were produced in Europe during this period, with a further 9,000 to 10,000 tonnes being imported in finished articles. This study suggests that the major stocks are in polyurethane foams with up to $30 \%$ in cars, $10 \%$ in furniture foam, and the remainder in textiles, building materials, packaging, and solid applications. Similar modelling undertaken primarily for BDE47 also yielded an estimate of 15,000 tonnes of the pentamix manufactured and used within the EU, and highlighted the importance of incineration routes to atmospheric emissions and so to subsequent long-range transport (Alcock et al., 2003). The Bromine Science Environmental Forum (BSEF) estimated the total market demand for the major commercial BFRs by region in 2001, the most recent year for which data are available (Table 1). This shows the dominance of tetrabromobisphenol-A (TBBP-A) and the deca-mix PBDE formulation in volume terms, and that Europe accounted for about $10 \%$ of TBBP-A usage, $57 \%$ of hexabromocyclododecane (HBCD) usage, $14 \%$ of the deca-mix usage, $16 \%$ of the octa-mix usage and $2 \%$ of the penta-mix usage in that year.

\section{Atmosphere}

ter Schure et al. (2004a) collected air and atmospheric bulk deposition samples on the island of Gotska Sandön in the Baltic Proper during a 10 week period in Autumn 2001. The sampling site was chosen because of its central position in the Baltic Sea, and because of the absence of local point sources of pollution. Ten brominated diphenyl ether (BDE) congeners were determined (BDE17, BDE28, BDE47, BDE85, BDE99, BDE100, BDE153, BDE154, BDE183 and BDE209). The median $\Sigma$ BDE concentration ( $\Sigma$ BDE is the sum of the concentrations of the congeners determined in each study) was $8.6 \mathrm{pg} \mathrm{m}^{-3}$, and the BDEs were mainly associated with particles. $\Sigma$ BDE concentrations were dominated by BDE209, which still has primary sources within the EU following the phasing-out of the penta-mix formulation, followed by BDE47 and BDE99. These background concentrations may therefore reflect either a change in use of commercial BDE formulations, or the greater affinity of BDE209 for particles relative to BD47 and BDE99. As PCB concentrations in Baltic air have been declining, the input of BDEs 
(especially BDE209) by atmospheric deposition to the Baltic Proper now exceeds that of the PCBs by a factor of almost 40 times.

Remberger et al. (2004) determined total HBCD ( $\Sigma$ HBCD) in a range of air samples from locations in Sweden using GC-EIMS. Close to a landfill site and the textile industry, HBCD concentrations were in the range 0.013 to $0.74 \mathrm{ng} \mathrm{m}^{-3}(\mathrm{n}=4)$, whilst in a single sample collected close to a factory producing extruded polystyrene plastics the concentration was $1,070 \mathrm{ng} \mathrm{m}^{-3}$. At urban sites in Stockholm, concentrations of HBCD were 0.076 and $0.61 \mathrm{ng} \mathrm{m}^{-3}$, whilst at more remote locations the range was $<0.001$ to 0.28 $n g \mathrm{~m}^{-3}(\mathrm{n}=6)$. These data suggest that HBCD may be sufficiently long-lived to undergo long-range atmospheric transport away from point sources of production and use.

Farrar et al.(2004) analysed air samples collected in November 2000 during the UK national bonfire festival held to commemorate the "Guy Fawkes gunpowder plot" of 1605. Many thousands of bonfires are lit during the evening of 5 November, both as part of public displays and in people's gardens. As would be expected, concentrations of PAH increased sharply in response to the widespread combustion, but levels of BDEs also increased at the suburban sampling location, to a greater extent than those of the PAH. Concentrations of BDE47 and BDE99 rose from ca. $2 \mathrm{pg} \mathrm{m}^{-3}$ to 7.5 and $14 \mathrm{pg} \mathrm{m}^{-3}$, respectively, with over $95 \%$ being particle-associated. The authors hypothesized that products treated with the penta-mix PBDE formulation (notably household furnishing foams and textiles) were being burned on private bonfires. The mixture of BDEs in the air during the festival was enriched in higher brominated congeners (BDE99, BDE153 and BDE154) compared to that in background air. The authors also calculated that to generate an air concentration of ca. $10 \mathrm{pg} \mathrm{m}^{-3}$ for BDE99 (cf. the measured peak concentration of $14 \mathrm{pg} \mathrm{m}^{-3}$ ), $1.3 \mathrm{~kg}$ of PBDE would need to be emitted.

Lee et al. (2004) determined atmospheric concentrations of BDEs at 2 rural/semi-rural sites in England, and 1 remote site on the west coast of Ireland in 2001 and in 2000, respectively $(n=108)$. $\Sigma$ BDE concentrations at Mace Head, Ireland, were 0.22 to $5.0 \mathrm{pg}$ $\mathrm{m}^{-3}$ with a mean of $2.6 \mathrm{pg} \mathrm{m}^{-3}$ and were controlled primarily by advection. $\Sigma$ BDE concentrations at Hazelrigg (NW England) were 2.8 to $37 \mathrm{pg} \mathrm{m}^{-3}$ with a mean of $12 \mathrm{pg} \mathrm{m}^{-}$ ${ }^{3}$, and at Chilton (SW England) were 3.4 to $33 \mathrm{pg} \mathrm{m}^{-3}$ with a mean of $11 \mathrm{pg} \mathrm{m}^{-3}$. The congener profile was, on average, similar to that of the commercial penta-mix PBDE formulation. At the two English sites in the summer, BDE concentrations were strongly influenced by temperature, indicating that land/air exchange processes play an important role in determining atmospheric concentrations.

BDEs were determined in precipitation falling in southern Sweden during a 2 week period in 2000 (ter Schure and Larsson, 2002). The particle-associated and "dissolved" phases were separated during sampling. $65 \pm 18 \%$ of $\Sigma \mathrm{BDE}$ was found to be particle-associated. The volume weighted mean concentration of $\Sigma B D E$ (9 congeners) in rain was $209 \mathrm{pg} \mathrm{l}^{-1}$, and the total deposition rate was $2 \pm 1 \mathrm{ng} \Sigma \mathrm{BDE} \mathrm{m} \mathrm{m}^{-2} \mathrm{day}^{-1}$. The congener profile in both phases of the total deposition was dominated by BDE209, and thereafter BDE47, BDE99 
and BDE183, representing inputs from all three commercial PBDE formulations. As has been observed for other POPs (persistent organic pollutants), it seems that particleassociated BDEs are effectively removed during small precipitation episodes, and that particle scavenging is an important mechanism for the wet deposition of BDEs.

Jaward et al. (2004a) studied a total of 71 passive air samples using semi-permeable membrane devices (SPMDs) for eight BDE congeners (BDE28, BDE47, BDE49, BDE75, BDE99, BDE100, BDE153 and BDE154) during a six week period in 2002 at remote/rural/urban locations across 22 countries in Europe. BDEs were detected in ca. $50 \%$ of the samples, and the equivalent $\Sigma \mathrm{BDE}$ air concentrations estimated from the passive sampler data ranged from 0.5 to $250 \mathrm{pg} \mathrm{m}^{-3}$. The focus of the most elevated concentrations was the UK, which has a history of PBDE production and has also been a major user of PBDE formulations due to stringent fire regulations within the country. The UK is clearly a regional source for BDEs to the European atmosphere and, in contrast, levels reaching Europe from the west (over the Atlantic Ocean) are low. Other high values were detected in urban centres in mainland Europe - samples from Athens, Bilthoven (Netherlands), Geneva, Milan and Seville, for example. Non-detectable/very low values occurred in remote/background sites, especially in Iceland, Ireland, Norway and Sweden, and values in eastern Europe were generally low. BDE47 and BDE99 contributed ca. $75 \%$ to $\Sigma$ BDE, similar to their proportion in the Bromkal 70-5DE pentamix technical product. In a subsequent study, Jaward et al. (2004b) determined the same eight BDE congeners in passive air samples collected at 11 sites along a latitudinal transect from the south of the UK to the north of Norway during 2000-2002. Equivalent concentrations of $\Sigma \mathrm{BDE}$ in air at background locations were 2.0 (range 1.1 to 2.5) and 1.1 (range 0.8 to 1.6) $\mathrm{pg} \mathrm{m}^{-3}$ in the UK and Norway, respectively. The proportion of the lighter BDEs decreased with increasing latitude while the heavier compounds were more evenly distributed, indicating that fractionation of the BDEs was occurring during atmospheric transport. BDE183, considered a marker compound for the octa-mix PBDE formulation, was also quantified and found at relatively high concentrations, equivalent to 1.9 to $16 \mathrm{pg} \mathrm{m}^{-3}$. This indicates that components of the octa-mix, which is principally used in moulded parts of computers, televisions, car parts and other products, are entering the environment. No defined latitudinal trend was observed for BDE183 which could be related to sources.

Harrad and Hunter (2004) determined BDEs (congeners BDE28, BDE47, BDE99, BDE100, BDE153 and BDE154) in passive air samples collected during 2003 using polyurethane foam (PUF) discs at 11 sites in the West Midlands (UK) centred on the city of Birmingham. Atmospheric SBDE concentrations ranged from 1.3 to $6.7 \mathrm{pg} \mathrm{m}^{-3}$, and higher concentrations were observed in samples from urban/suburban sites than at semirural/rural sites, with about a five-fold difference in concentration. The profiles were dominated by BDE47 and BDE99. In an earlier study, Harrad et al. (2004) determined BDEs (same congeners less BDE28) in 6 outdoor air samples collected in the city in July and August 2002 and April and May 2003. $\mathrm{BDDE}$ concentrations were in the range 10 to $33 \mathrm{pg} \mathrm{m}^{-3}$. 
A recent study has investigated whether release of BDEs takes place at a municipal solid waste incineration (MSW) facility (Agrell et al., 2004; ter Schure et al., 2004b). The rationale was that MSWs handle large quantities of waste and that the amounts of collected electronic waste are steadily increasing, and that plastic products may contain up to 32\% by weight of PBDE (WHO, 1994). During the year 2000, 2.35 Mt of household and industrial waste were incinerated at 22 plants in Sweden, and the volume of waste is increasing at approximately 2,500 tpa. The MSW plant studied, in Malmö, received 200 kt of waste in 2002, of which 2 kt was electronic waste. BDE congeners BDE28, BDE47, BDE66, BDE100, BDE153, BDE154, BDE183 and BDE209 were determined using GCECD. Data obtained were compared with similar measurements made at an urban reference site, where manufacture of concrete and asphalt is conducted, since this type of industry makes no use of brominated flame retardants.

$\Sigma$ BDE concentrations (gaseous + particulate phase concentrations) ranged from 2.2 and $21.3 \mathrm{pg} \mathrm{m}^{-3}$ at the MSW site, with a median value of $6.3 \mathrm{pg} \mathrm{m}^{-3}(\mathrm{n}=17)$ and from 0 to $26.7 \mathrm{pg} \mathrm{m}^{-3}$ at the reference site, with a median value of $3.5 \mathrm{pg} \mathrm{m}^{-3}(\mathrm{n}=19)$ (Agrell et al., 2004). Median values of BDE47 and BDE209 were 2.1 and $10.4 \mathrm{pg} \mathrm{m}^{-3}$ at the MSW and 1.7 and $6.5 \mathrm{pg} \mathrm{m}^{-3}$ at the reference site. Compared to other studies, the concentrations observed were relatively low, possibly as a result of sampling during October-March when temperatures and so evaporation are relatively low. Atmospheric bulk deposition samples were also collected and analysed (ter Schure et al., 2004b). Between 75 and 95\% of the deposited BDEs consisted of BDE47, BDE99 and BDE209. Concentrations in rain were significantly higher at the MSW than at the reference site, with median dry and wet deposition fluxes for $\Sigma$ BDE of 18.4 and $21.6 \mathrm{ng} \mathrm{m}^{-2}$ day $^{-1}$; and 7.0 and $6.8 \mathrm{ng} \mathrm{m}^{-2}$ day $^{-1}$, respectively. The authors suggest that treatment of waste is currently a source of "old" PBDEs to the environment, whereas the observed concentrations of BDE209 represent diffuse leakage from products still in current use. The emission of BDEs to the atmosphere from waste treatment should be considered as an important source when assessing the transport of these substances in the environment (Agrell et al., 2004).

\section{Sewage sludge}

Relatively few studies have been conducted of the contamination of sewage sludge in Europe, despite the fact that sewage sludge is considered to be one of the main sinks for polybrominated diphenyl ethers. The application of sewage sludge to agricultural land in many countries also increases the possibility of subsequent remobilization of these compounds.

Sewage sludge samples from three sewage treatment plants (STPs) in Stockholm collected in 1997-98 contained measurable amounts of BDEs, HBCD and TBBP-A (Sellström et al., 1999). Based on these results, the Swedish Environmental Protection Agency initiated a larger study to determine the extent of the contamination in sewage sludges from STPs across Sweden. As a result, sewage sludge samples were collected in 2000 from 50 STPs 
and were analyzed for BDE47, BDE99, BDE100, BDE153, BDE154, BDE209, HBCD (determined using GC-ECNIMS), TBBP-A and BB209. Samples represented major cities (Stockholm, Gothenburg, Malmö), towns with possible point sources and STPs of differing sizes randomly scattered around the country. BDE209 was the compound usually found at the highest concentrations in most sludges. The congener profile of congeners BDE47, BDE99, BDE100, BDE153 and BDE154 in all sludges was similar to that of the penta-mix PBDE technical product Bromkal 70-5DE, which is probably the original source. Concentrations of the lower brominated BDEs were fairly similar in all sewage sludge samples, indicating diffuse leaching of these from products into wastewater streams (Table 2). The lack of point sources for this product is probably a result of the phasing out of the penta-mix product in the EU and the fact that Sweden no longer imports such products.

Two to eight times higher concentrations of BDE209, HBCD and/or TBBP-A were found in sludge samples from a few STPs with known, or suspected, point sources connected to them. These were textile industries, producers of extruded polystyrene and a company that upholsters cars. Otherwise, BDE209 and HBCD concentrations did not vary much between STPs. For TBBP-A, the picture is less clear, as there is a tendency for large STPs to have lower concentrations than mid-size and small STPs. The TBBP-A content in sludge is probably a result of diffuse leaching, but other factors may also play a role. Aside from these exceptions, there were no correlations seen between concentrations of BFRs in sludge and the capacity of the STP. No north-south gradient in concentrations was seen, indicating that loads into sewage treatment plants are not related to surface deposition and subsequent washout into stormwater streams. These results indicate that the major source of background levels of BFRs in sludge is from diffuse leaching of these from products into wastewater streams from users, households and industries generally. These results also indicate that at least four technical flame retardant products have been, or are being, used in Sweden - the penta-mix and deca-mix PBDE formulations, HBCD and TBBP-A. No correlations were seen between the concentrations of the different flame retardant products, indicating that they are being used independently of one other.

HBCD and TBBP-A were analysed in samples collected from STPs in Ireland, the Netherlands and the UK on a diastereomer specific basis using LC-MS (de Boer et al., 2002). In addition, BDEs were determined in samples from the Netherlands. The STPs sampled were of varying capacity, from 4,750 to 750,000 population equivalents. For the BDEs in samples from the Netherlands, in most cases only the congeners BDE47, BDE99, BDE100 and BDE209 were detected. Occasionally BDE154 and BDE183 were also found. HBCD and TBBP-A were found in UK sewage sludges $(n=5)$ at concentrations ranging from 530 to 2,680 and 16 to $112 \mu \mathrm{g} \mathrm{kg}{ }^{-1}$ dry weight, respectively. In Ireland, the corresponding ranges were 150 to 9,120 and $<2$ to $192 \mu \mathrm{g} \mathrm{kg}^{-1}$ dry weight, respectively (n =6). In the Netherlands, the corresponding ranges were $<0.4$ to 93 and 2.1 to $600 \mu \mathrm{g} \mathrm{kg}^{-1}$ dry weight, respectively $(n=10)$. For HBCD, all 3 diastereomers $(\alpha-, \beta$ - and $\gamma$-) were detected in varying amounts. The methyl derivative of TBBP-A was not detected in the 
STP samples from Ireland and the UK, although it was occasionally detected in some sewage sludge samples from the Netherlands.

Christensen et al. (2003) determined BDEs (BDE17, BDE28, BDE47, BDE49, BDE66, BDE85, BDE99, BDE100, BDE153, BDE154, BDE183 and BDE209) in a sewage sludge sample from Bjergmarken STP in Roskilde, Denmark. The $\Sigma$ BDE concentration (all congeners except BDE209) was $238 \pm 23 \mu \mathrm{g} \mathrm{kg}^{-1}$ dry weight, and of BDE209 was $248 \pm$ $81 \mu \mathrm{g} \mathrm{kg}^{-1}$ dry weight. Sewage sludge from 6 STPs in Spain collected during 2002 were analysed for BDEs (congeners BDE7, BDE15, BDE17, BDE28, BDE47, BDE49, BDE66, BDE85, BDE99, BDE100, BDE119, BDE153, BDE154 and BDE209) by Fabrellas et al. (2004). All congeners except BDE209 were determined using GC-EIMS/MS, and BDE209 using GC-ECNIMS. In all cases the dominant congener was BDE209 (93-99\%) with minor quantities of BDE47, BDE99, BDE100, BDE153 and BDE154. इBDE concentrations ranged from 844 to $18,100 \mu \mathrm{g} \mathrm{kg}^{-1}$ dry weight, and the highest concentration was associated with an industrial area with mainly textile manufacture.

Moche and Thanner (2004) determined BDEs (BDE11, BDE17, BDE25, BDE28, BDE47, BDE49, BDE77, BDE99, BDE100, BDE116, BDE138, BDE140, BDE153, BDE154, BDE155, BDE166, BDE181 and BDE183) in effluents and sludges from 36 STPs and wastewater treatment plants in Austria. The dominant congeners were BDE47, BDE99, BDE100, BDE153 and BDE183, and no significant differences were observed between urban and industrial effluents, with the single exception of one effluent from a textile factory. This showed much higher concentrations ( $\Sigma$ BDE $186 \mathrm{ng} \mathrm{l}^{-1}$, exceeding the maximum for the other samples by approximately a factor of 4 times) ca. $40 \%$ of which was contributed by BDE183.

\section{Sediments and soils}

Lacorte et al. (2003) determined 40 mono- to hepta-BDE congeners in river and coastal sediments from the eight major river basins of Portugal. BDEs were detected in all 32 samples analysed, indicating diffuse sources of contamination. Maximum concentrations were observed in sediments collected close to urban and industrial areas. Profiles along the different rivers from inland to the sea revealed an increase of concentration towards the river mouth (in the Tejo, which flows through Lisbon, to a $\Sigma$ BDE concentration of 21 $\mu \mathrm{g} \mathrm{kg}{ }^{-1}$ dry weight), generally decreasing to ca. $0.5 \mu \mathrm{g} \mathrm{kg}^{-1}$ in coastal sediments. In the Formosa, Sado and Tejo, di-BDE congeners (BDE7, BDE11, BDE12+13 and BDE15) were detected, due either to a specific source or the possible environmental transformation of more highly brominated congeners. Different congener-specific profiles were found in each of the river basins studied, which suggests varying source inputs in the different locations.

de la Cal et al. (2003) determined seven BDE congeners (BDE47, BDE99, BDE100, BDE118, BD153, BDE154 and BDE183) in two river sediments and five marine sediments collected around Barcelona and Tarragona in Catalonia, NE Spain. $\Sigma$ BDE 
concentrations ranged from 0.86 to $2.49 \mu \mathrm{gg}^{-1}$ dry weight. In the river sediments BDE99 was present at the highest concentrations, followed by BDE183, whilst in the marine sediments BDE183 was always present at the highest concentration. This suggests the use of the commercial octa-mix PBDE formulation in the local area. BDE209 was also determined in five river and eight marine sediments collected in the same area in 2002 (Eljarrat et al., 2004a). BDE209 was detected in all samples, and concentrations of BDE209 in the riverine and marine sediments ranged from 2.1 to 40 and 3.0 and $132 \mu \mathrm{g}$ $\mathrm{kg}^{-1}$ dry weight, respectively. In general terms, these concentrations are of a similar order to those reported previously for sediments from the River Viskan in Sweden, which varied from 68 to $390 \mu \mathrm{g} \mathrm{kg}^{-1}$ dry weight (Sellström et al., 1998). In the study by Eljarrat et al. (2004a), additional chromatographic peaks due to bromine-containing compounds were detected, eluting between BDE183 and BDE209, in all of the sediment samples analysed. These seven peaks were identified as potential octa- and nona-BDE congeners, however their identity could not be established due to a lack of standard materials. Eljarrat et al. (2004b) determined BDEs (40 congeners of all degrees of bromination, but data reported for only seven; BDE47, BDE100, BDE118, BDE153, BDE154, BDE183 and BDE209) and HBCD (by GC-ECNIMS) in sediments from 4 sites in the Cinca River, NE Spain. $\Sigma \mathrm{BDE}$ and HBCD concentrations ranged from 2.5 to 42 and not detected to $514 \mu \mathrm{g} \mathrm{kg}^{-1}$ dry weight, respectively. BDE209 dominated the BDE congener profile.

Moche and Stephan (2003) determined BDEs (17 congeners) in 13 sediments and 2 samples of suspended particulate matter (SPM) from the River Danube in Austria. $\Sigma$ BDE concentrations in sediments ranged from 0.29 to $10.4 \mu \mathrm{g} \mathrm{kg}^{-1}$ dry weight, and were 0.38 and $1.1 \mu \mathrm{g} \mathrm{kg}^{-1}$ dry weight in the SPM samples. BDE47 and BDE99 dominated the sediment profiles, but in the SPM samples BDE181 and BDE183 were also present at high concentrations.

Sawal et al. (2004) determined BDEs (congeners BDE28, BDE47, BDE66, BDE71, BDE75, BDE85, BDE99, BDE100, BDE138, BDE153, BDE154, BDE183, BDE190 and BDE209) in surface sediment samples from the River Elbe, Germany and the Czech Republic, taken in 2002 using GC-ECNIMS. BDE209 was detected at concentrations ranging from 0.5 to $17 \mu \mathrm{g} \mathrm{kg}^{-1}$ dry weight (10 to $230 \mu \mathrm{g} \mathrm{kg}^{-1}$ organic carbon; $\mathrm{n}=29$ ), representing almost $80 \%$ of $\Sigma$ BDE. Of the other congeners studied, BDE47, BDE85, BDE99, BDE100, BDE153, BDE154 and BDE183 were detected in most samples at low concentrations. In the Czech Republic, a few samples showed higher percentages of tetrato hexabrominated congeners, suggesting local inputs of the penta-mix PBDE formulation.

Sediments from the River Viskan in Sweden, upstream and downstream of the textile industry, showed $\Sigma$ HBCD concentrations determined using GC-EIMS of $<0.1$ to 0.2 and 1 to $25 \mu \mathrm{g} \mathrm{kg}^{-1}$ dry weight, respectively (Remberger et al., 2004). Sediments from urban environments yielded concentrations of 0.2 to $1.5 \mu \mathrm{g} \mathrm{kg}-1$ dry weight $(\mathrm{n}=6)$.

Morris et al. (2004) determined HBCD and TBBP-A in river and estuarine sediment samples from Belgium, The Netherlands and the UK using LC-MS. HBCD was detected 
in all sediments analysed, and the highest concentrations of both $\Sigma$ HBCD and TBBP-A were found in freshwater sediments from the River Skerne, NE England, close to a site of brominated flame retardant manufacture. The maximum values were $\Sigma$ HBCD 1,700 $\mu \mathrm{g}$ $\mathrm{kg}^{-1}$ and TBBP-A 9,800 $\mu \mathrm{g} \mathrm{kg}^{-1}$, both on a dry weight basis. Mean concentrations in the River Tees, further downstream, were 510 and $25 \mu \mathrm{g} \mathrm{kg}^{-1}$ dry weight, respectively, and neither HBCD nor TBBP-A were detected in sediments from Tees Bay, beyond the estuary mouth. HBCD and TBBP-A were also detected in sediments from the Scheldt basin (38 to 950 and 0.5 to $24 \mu \mathrm{gg}^{-1}$ dry weight, respectively), from the western Scheldt ( 0.7 to 99 and 0.3 to $1.3 \mu \mathrm{g} \mathrm{kg}^{-1}$ dry weight, respectively), from other Dutch rivers $(<0.2$ to 9.9 and 0.8 to $4.0 \mu \mathrm{g} \mathrm{kg}^{-1}$ dry weight, respectively) and from UK rivers other than the Skerne and Tees (6.0 to 322 and $<2$ to $5.0 \mu \mathrm{g} \mathrm{kg}^{-1}$ dry weight, respectively). The isomer profile of HBCD in most samples was similar to that of the commercial formulation, dominated by $\gamma$-HBCD.

Kilemade et al. (2004) determined BDEs (congeners BDE28, BDE47, BDE66, BDE71, BDE75, BDE77, BDE85, BDE99, BDE100, BDE119, BDE138, BDE153, BDE154, BDE183, BDE190 and BDE209) and HBCD (using GC-EIMS) in the $<63 \mu \mathrm{m}$ fraction of surface sediments from three sites in Cork Harbour, Ireland and a reference site. HBCD was detected at all the harbour sites, at concentrations ranging from 0.4 to $5.3 \mu \mathrm{gg}^{-1} \mathrm{dry}$ weight. BDEs were detected at low concentrations at two of the harbour sites, with $\Sigma \mathrm{BDE}$ concentrations of 1.8 and $1.9 \mathrm{\mu g} \mathrm{kg}^{-1}$ dry weight.

Schlabach et al. (2004) determined BDEs (congeners BDE28, BDE47, BDE49+71, BDE99, BDE100, BDE138, BDE153, BDE154, BDE183 and BDE209) and HBCD and TBBP-A in sediments from Lake Mjøsa, Norway, using GC-EIMS. $\Sigma$ BDE concentrations were in the range 0.6 to $27 \mu \mathrm{g} \mathrm{kg}^{-1}$ dry weight, with the highest concentrations near the inlet at the northern end of the lake and the lowest close to the outlet in the south. Tri- to hexa-BDEs (BDE47, BDE99, BDE100, BDE153 and BDE154) constituted 60-70\% of $\Sigma$ BDE in sediments from the northern part of the lake, whilst elsewhere BDE209 dominated (50-90\% of $\Sigma$ BDE). HBCD was detected in only one sediment collected close to Lillehammer. Only $\beta$-HBCD was found, at $7.9 \mu \mathrm{g} \mathrm{kg}^{-1}$ dry weight. TBBP-A was detected at low concentrations (0.04 to $0.13 \mu \mathrm{g} \mathrm{kg}^{-1}$ dry weight).

Three dated sediment cores from locations in western Europe were analysed for 14 BDE congeners (Zegers et al., 2003). Cores from the Drammenfjord (Norway), the western Wadden Sea (The Netherlands) and Lake Woserin (Germany) showed a time-dependent pattern in the distribution of BDEs since the start of production of PBDE formulations. Two of the three commercial formulations could be distinguished. The penta-mix formulation is clearly present from the beginning of the 1970s, but the deca-mix only appears in the late 1970s. This is in agreement with data for the industrial production of these two formulations. It appears that the octa-mix is absent as its presumed marker compound, BDE183, was not detected in any of the cores. In the cores from the Netherlands and Germany, concentrations of BDE congeners associated with the pentamix were levelling off in the most recent layers (1995 and 1997 - concentrations 
normalised to total organic carbon), whereas those in the Drammenfjord were still increasing in 1999. The levels of BDE209 decreased in the most recent layers of all three cores. The absence of all BDE congeners in the older (deeper) layers of all 3 cores, as well as in several 100 to 150 million year old layers of clay from Kimmeridge, UK, indicated that these BDE congeners are not produced naturally. In the case of the Lake Woserin core, the concentrations of BDE congeners observed are probably due wholly to atmospheric transport.

Two $50 \mathrm{~cm}$ sediment cores were collected from the Scheldt estuary in 2000 and BDEs (BDE28, BDE47, BDE66, BDE85, BDE99, BDE100, BDE138, BDE153 and BDE154) determined with depth (Covaci et al., 2002a). $\Sigma$ BDE concentrations in the two cores ranged from 1.4 to 179 and 1.4 to $272 \mu \mathrm{g} \mathrm{kg}^{-1}$ dry weight, respectively. The BDE profile matched the composition of the commercial penta-mix formulation, and the concentrations showed a steep increase in the surface layers, probably during the few years immediately prior to sampling, although the cores were not dated.

Voorspoels et al. (2004a) have analysed sediments from the Belgian North Sea, the Western Scheldt Estuary and freshwater watercourses from the Scheldt basin for eight BDE congeners (BDE28, BDE47, BDE99, BDE100, BDE153, BDE154, BDE183 and BDE209). Concentrations of summed tri- to hepta-BDEs in the sediments were $<0.2 \mu \mathrm{g}$ $\mathrm{kg}^{-1}$ dry weight for samples from the Belgian North Sea, whilst in those from the Scheldt Estuary this sum ranged from $<0.20$ to $0.41 \mu \mathrm{g} \mathrm{kg}^{-1}$ dry weight. BDE209 was detected in $83 \%$ of the samples from the Belgian North Sea and in all samples from the Scheldt Estuary, with a maximum concentration of $1200 \mathrm{\mu g} \mathrm{kg}^{-1}$ dry weight being observed in the Scheldt Estuary. Compared to the marine and estuarine locations, the sediments from the freshwater watercourses were relatively more polluted with tri- to hepta-BDEs $(<0.20-$ $19 \mu \mathrm{g} \mathrm{kg}^{-1}$ dry weight), while concentrations of BDE209 were up to $320 \mu \mathrm{g} \mathrm{kg}^{-1}$ dry weight. The contribution of BDE209 to the total amount of BDEs had a larger variation for the freshwater locations than for the Scheldt Estuary, suggesting a different input of BDEs to the freshwater than that to the marine sites.

Reference (non-treated) and sewage-sludge amended soils (1 - 3 tonnes dry matter (DM) hectare $^{-1}$ year $^{-1}$ ) from three agricultural research stations in Sweden (Igelösa, Peterstorp, Lanna) were sampled in 2000 and analyzed for BDE47, BDE66, BDE99, BDE100, BDE153, BDE154 and BDE183 (Matscheko et al., 2002). In addition, soil samples were taken from two privately owned farms. At one farm, a total of 614 tonnes of sewage sludge (DM) was used on 25 hectares as fertilizer during 1978-1982, the equivalent of 25 tonnes hectare $^{-1}$ for this period. At this time, a textile industry that used PBDE formulations in their production was connected to the local STP. At the other farm, fields were flooded the summer before by the river Viskan, which contains sediments which are highly contaminated with BDEs (Sellström et al., 1998). Reference samples were also taken from the farms, and earthworms collected at all soil sampling sites were also analyzed as well. The BDE congener profile in all soil samples was dominated by BDE47 
and BDE99. The concentrations in reference soils from the agricultural research stations varied from 29 to $95 \mathrm{ng} \mathrm{kg}^{-1} \mathrm{DM}$ for the sum of BDE47, BDE66, BDE99, BDE100, BDE153, BDE154 and -BDE183. For samples from the two farms, the reference concentrations were 110 and $190 \mathrm{ng} \mathrm{kg}^{-1} \mathrm{DM}$ for $\Sigma \mathrm{BDE}$. In plots to which sewage sludge had been applied, soil concentrations at the research stations increased to between 75 and $930 \mathrm{ng} \mathrm{kg}^{-1} \mathrm{DM}$. At the farm at which sewage sludge had been applied, the treated field had soil concentrations of $840,000 \mathrm{ng} \mathrm{kg}^{-1} \mathrm{DM}$ for $\Sigma$ BDE. Soil from the flooded field of the other farm contained 4,000 $\mathrm{ng} \mathrm{kg}^{-1} \mathrm{DM}$ for $\Sigma$ BDE. The impact of applying $1-3$ tonnes hectare ${ }^{-1}$ year $^{-1}$ of sludge was determined by calculating the ratios of the concentrations of the compounds in the sludge-treated soil to those in the reference soil from the same site ( $\mathrm{S} / \mathrm{R}$ ratio). The $\mathrm{S} / \mathrm{R}$ ratios for the individual BDE congeners were greater than 1 (range 3 to 12) indicating that sewage sludge application is a source of BDE contamination in agricultural soils. The largest increase in the S/R ratios (2,100 to $12,000)$ was found at the private farm, where large amounts of sludge had been applied approximately 20 years ago. This indicates that these substances can have quite long residence times in soils. Accumulation of the compounds in earthworms from the sites yielded a direct relationship between the concentrations in the soil and concentrations in the worms. The biota -soil accumulation factors (BSAFs) of BDE congeners BDE47, BDE99 and BDE100 were around 5 (organic matter/lipids), similar to those obtained for the ortho-substituted chlorobiphenyls. Thus, earthworms living in highly contaminated soils will accumulate high tissue BDE concentrations and, as these animals represent the base of the terrestrial food chain for many organisms, this forms a pathway for the accumulation of BDEs in organisms at higher trophic levels.

BDEs were determined in soil samples collected along a latitudinal transect through the UK and Norway, at remote/rural woodland (both coniferous and deciduous) and grassland sites (Hassanin et al., 2004). Concentrations for $\Sigma$ BDE ranged from 65 to 12,000 ng kg-1 dry weight. BDE congeners BDE47, BDE99, BDE100, BDE153 and BDE154, the major constituents of the commercial penta-mix PBDE formulation, dominated the average congener pattern in the soils. This was interpreted as evidence that transfer of the congeners from materials treated with the penta-mix product from source to air to soil occurs with broadly similar efficiency, and that there is little degradation of the congeners by processes acting either during atmospheric transport or within the soils themselves. BDE183, often considered as a marker compound for the octa-mix PBDE formulation, was detected at concentrations of $<9$ to $7,000 \mathrm{ng} \mathrm{kg}^{-1}$ dry weight (median concentration ca. $50 \mathrm{ng} \mathrm{kg}^{-1}$ ). BDE183 was a minor contributor to $\Sigma$ BDE in most soils, but it was a major contributor in some soils from northern England. Forest soils tended to have higher concentrations than grasslands. There was evidence of latitudinal fractionation of the BDE congeners, with the relative amounts of BDE47 and the lighter congeners increasing to the north (with increasing distance from source areas) while the proportion of BDE99 and the heavier congeners decreased. Plots of BDE congener concentrations against percentage soil organic matter yielded different slopes for different congeners. Steeper slopes were generally observed for lighter congeners (e.g. BDE47), indicating that they have undergone some air-surface exchange ("hopping"), whilst those heavier congeners 
(e.g. BDE153) were close to zero, indicating that they are retained more effectively by soil following deposition.

\section{Biota}

\subsection{Bird tissues and bird's eggs}

Baltic guillemot (Uria aalge) eggs from Stora Karlsö in the Baltic Sea sampled between 1969 and 2001 were analysed for BDE47, BDE99, BDE100 and HBCD using GCECNIMS (Sellström et al., 2003). Concentrations of the three BDE congeners increased from the 1970s to the 1980s, peaking around the mid- to late-1980s. These peaks were followed by a rapid decrease during the remainder of the study period, with the concentrations of the major BDE congener (BDE47) below $100 \mu \mathrm{gg}^{-1}$ lipid weight at the end of the period. This corresponds to $<10 \%$ of the peak concentration. Concentrations of HBCD showed a similar pattern over time. After a peak in the mid-1970s followed by a decrease, the concentrations increased during the latter part of the 1980s. During the recent 10 year period no significant change has occurred and the annual mean concentrations are fairly stable (ca. $140 \mu \mathrm{g} \mathrm{kg}^{-1}$ lipid weight).

Herzke et al. (2003) studied BDEs in muscle tissue, liver and guano from glaucous gull (Larus hyperboreus) on Bjørnøya (Bear Island), $500 \mathrm{~km}$ to the north of the Norwegian mainland, halfway between Norway and Spitsbergen $\left(74^{\circ} \mathrm{N}, 19^{\circ} \mathrm{E}\right)$. Gut samples and muscle tissue were also collected from kittiwake (Rissa tridactyla) and little auk (Alla alle) (Herzke et al. 2004). Muscle tissue and guano from glaucous gull represent the most contaminated sample materials ever collected from Arctic seabirds, affecting the almost pristine ecosystem on Bjørnøya. The median BDE47 concentration found in the glaucous gull muscle tissue was $860 \mu \mathrm{g} \mathrm{kg}^{-1}$ lipid weight, which is not unusually high when compared to that reported for muscle tissue from predatory birds such as the osprey in

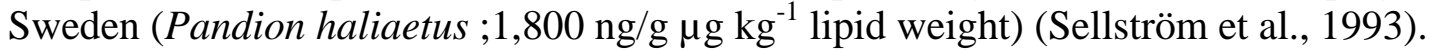
However, very few data are available so far for seabird tissues. A surprisingly high concentration of BDE153 was detected in muscle samples of glaucous gull (420 $\mathrm{gg} \mathrm{kg}^{-1}$ lipid weight).

Lindberg et al. (2004) analysed a range of BFRs in peregrine falcon (Falco peregrinus) eggs collected in northern and southwestern Sweden in 1987-1999. The compounds analysed were constituents of the PBDE penta-mix (BDE47, BDE99, BD100, BDE153 and BDE154), octa-mix (BDE183), and deca-mix (BDE209) formulations, a hexabrominated biphenyl (BB153) and HBCD (using GC-ECNIMS). The eggs represented females from three different breeding populations, including one captive population raised on a controlled diet of domestic chickens. The northern wild population feeds on waders and ducks and the southern wild population feeds on birds in the terrestrial food web. All BFRs analysed were detected, including BDE183 and BDE209, and concentrations were much higher in wild falcons than in captive birds $(\mathrm{p}<0.001$ for all compounds) (Figure 1). The mean concentrations of the sum of BDE47, BDE99, BDE100, BDE153, BDE154, BDE183 and BDE209 were 3700 and $4500 \mu \mathrm{gg}^{-1}$ lipid 
weight for the southern and northern populations, respectively and $56 \mathrm{\mu g} \mathrm{kg}^{-1}$ lipid weight in the captive population. However, individual $\Sigma \mathrm{BDE}$ concentrations were as high as $39,000 \mathrm{~g} \mathrm{~kg}^{-1}$ lipid weight, some of the highest concentrations seen in wildlife so far. For HBCD, mean concentrations in the wild populations were $520 \mathrm{\mu g} \mathrm{kg}^{-1}$ lipid weight (southern) and $220 \mu \mathrm{g} \mathrm{kg}^{-1}$ lipid weight (northern) and for BB153, means were $99 \mathrm{\mu g} \mathrm{kg}^{-1}$ lipid weight (southern) and $120 \mathrm{\mu g} \mathrm{kg}^{-1}$ lipid weight (northern). Means for the captive population were below the detection limit for HBCD and $40 \mathrm{\mu g} \mathrm{kg}^{-1}$ lipid weight for $\mathrm{BB} 153$. The BDE congener patterns were dominated by the penta- and hexa-BDEs, BDE99, BDE100 and BD153, followed by HBCD. BDE47, BDE154 and BDE183 were present in lower, but similar, concentrations, followed by BDE209 and BB153. The captive population had a different congener profile, dominated by BDE153 and BB153, followed by BDE183 and BDE209, then HBCD and BDE154, and low concentrations of BDE47, BDE99 and BDE100. These differences can only be explained by differences in exposure due to diet, although differences in metabolic capacity can also contribute to differences between species.

These congener patterns can be contrasted with those in piscivorous birds, such as guillemots and cormorants (Phalocrocorax carbo) (Law et al., 2002), in which BDE47 is the dominant congener. Also, it seems that terrestrial organisms may be more highly exposed to the more highly brominated BDE congeners than are aquatic organisms. A similar congener pattern to that seen in peregrine falcons from Sweden, with the presence of BDE209, has also been observed in peregrines from Norway (Herzke et al., 2001), and other terrestrial species such as golden eagle and merlin, also from Norway (Herzke et al., in press). In this study, 62 deserted or addled eggs from six species of predatory birds collected between 1991 and 2002 throughout Norway were analysed for BDEs (congeners BDE28, BDE47, BDE99, BDE100, BDE138, BD153, and BDE154) and brominated biphenyls (congeners BB15, BB49, BB52, BB101 and BB153). The species investigated were white-tailed sea eagle (Haliaeetus albicilla), merlin (Falco columbarius), golden eagle (Aquila chrysaetos), osprey, peregrine falcon and goshawk (Accipiter gentilis), and were selected as representative of different food chains, habitats and migratory behaviour. BDE47, BDE99 and BDE153 were the dominant BDE congeners, with species-dependent compound ratios. BDE153 was the most abundant BDE congener in eggs of peregrine falcon, golden eagle and merlin, and BDE47 in those of the other species. The highest $\Sigma$ BDE concentration was found in eggs of white-tailed sea eagle, up to $800 \mathrm{\mu g} \mathrm{kg}^{-1}$ wet weight (median value $184 \mathrm{\mu g} \mathrm{kg}^{-1}$ wet weight) followed by peregrine falcon and osprey (median $\Sigma$ BDE 155 and $105 \mathrm{gg} \mathrm{kg}^{-1}$ wet weight, respectively). Golden eagle eggs showed the lowest concentrations. Generally, concentrations were comparable to those reported for peregrines from Sweden (Lindberg et al., 2004). A subset of 23 eggs representing all species except goshawk were analysed for BDE183 and BDE209. BDE209 was detected in eggs from all species at low concentrations ( 0.3 to $4.0 \mu \mathrm{g} \mathrm{kg}^{-1}$ wet weight), comparable to data presented for birds of prey from Sweden and the UK (de Boer et al., 2004; Lindberg et al., 2004). BB101 and BB153 were found in eggs of all bird species investigated. Unidentified penta- and hexabrominated biphenyls were detected, particularly in eggs of white-tailed sea eagle peregrine falcon and goshawk. In addition, 
TBBP-A was analysed in eight eggs by GC-MS, and detected in all. Concentrations of all flame retardant compounds were highly variable, and even some samples from remote locations yielded high concentrations. The number of eggs analysed and the high variability precluded the investigation of spatial and temporal trends.

de Boer et al. (2004) have determined HBCD in peregrine falcon eggs and sparrowhawk (Accipiter nisus) muscle from the UK using LC-MS. HBCD diastereomers were detected in 13 of the 51 samples of falcon eggs (range of $\Sigma$ HBCD concentrations 71 to 1,150 $\mu \mathrm{g}$ $\mathrm{kg}^{-1}$ lipid weight) and 8 of the 65 samples of sparrowhawk muscle (range 22 to 19,200 $\mu \mathrm{g}$ $\mathrm{kg}^{-1}$ lipid weight). In the remainder of the samples no HBCD could be detected. All three HBCD diastereomers could be detected in both species, although the patterns of occurrence varied from sample to sample. Samples were collected between 1973 and 2002, but no time trend could be detected in $\Sigma$ HBCD concentrations.

de Boer et al. (2004) also conducted an extensive study of the occurrence and time trends of BDE209 in predatory birds and water birds, using samples from the databank held by the Centre for Ecology and Hydrology in the UK. BDE209 was found to be present in peregrine falcon eggs, as well as in muscle and liver tissue, but at 3- to 4-fold lower concentrations than those observed in peregrine falcon eggs from Sweden (up to $108 \mu \mathrm{g}$ $\mathrm{kg}^{-1}$ lipid weight as compared to a maximum concentration of $412 \mu \mathrm{g} \mathrm{kg}^{-1}$ lipid weight in Swedish eggs). Other UK predatory birds (6 species) also contained BDE209, although at relatively low concentrations. Some water birds (1 heron, 2 great crested grebes, 1 sea eagle) showed measurable concentrations of BDE209, but BDE209 could not be detected in the majority of water birds, nor in golden eagle, marsh harrier, osprey and gannets (all from the UK), and cormorants from the Netherlands. Terrestrial birds clearly showed higher BDE209 concentrations than water birds, confirming the hypothesis that water acts as a barrier in the transfer of BDE209 from suspended particulate material and sediment to aquatic organisms. BDE209 bioaccumulates in terrestrial birds to only a limited extent. A statistically significant increase of concentrations of BDE209 in peregrine falcon eggs over the period 1975 to 1995 was observed, as well as a significant decrease from 1995 to 2001. This suggests a correlation with consumption of the deca-mix formulation in the UK, with a peak in 1989 and a decrease since that time. Data for sparrowhawks (19732001) did not show any significant trend, but more positive samples were observed in samples from later years.

Morris et al. (2004) determined HBCD in the livers of two cormorants from the UK using LC-MS, and found $\Sigma$ HBCD concentration of 1,090 and 1,320 $\mu \mathrm{g} \mathrm{kg}^{-1}$ lipid weight. Concentrations of TBBP-A were up to an order of magnitude lower (2.5 and $14 \mu \mathrm{g} \mathrm{kg}{ }^{-1}$ lipid weight).

Jaspers et al. (2004) have determined BDEs (congeners BDE28, BDE47, BDE99, BDE100, BDE153, BDE154 and BDE183) in eggs of the little owl (Athene noctua) from Charleroi, Belgium. The little owl is a small sedentary predator, and so provides a very suitable biomonitoring species. It feeds on a variety of prey, including mammals, birds, 
reptiles, amphibians, earthworms and beetles, depending on the season and local availability. $\Sigma$ BDE concentrations in the eggs ranged from 29 to $572 \mu \mathrm{g} \mathrm{kg}^{-1}$ lipid weight, with a mean value of $108 \mu \mathrm{g} \mathrm{kg}^{-1}$. The congener profile was dominated by BDE99 and BDE153, followed by BDE47. BDE183 was detected in all samples ( $\mathrm{n}=39$; range 4.1 to $31 \mu \mathrm{gg}^{-1}$ lipid weight) and contributed, on average, 9.4\% to the $\Sigma$ BDE concentration. As in previous studies, this suggests that the octa-mix PBDE formulation is more prevalent in the terrestrial than in the aquatic environment. BB153 was also detected in all egg samples, at concentrations ranging from 0.6 to $5.6 \mu \mathrm{g} \mathrm{kg}^{-1}$ lipid weight. BDE 209 and HBCD had a very low detection frequency (1 and 2 out of 40 eggs, respectively).

Voorspoels et al. (2004b) have investigated the levels and distribution of tri- to hepta-BDEs (congeners BDE28, BDE47, BDE99, BDE100, BDE153, BDE154 and BDE183) in muscle, liver, fat and brain from several species of birds of prey from Belgium: (27 buzzards (Buteo buteo), 7 sparrowhawks and 8 owls). $\Sigma$ BDE concentrations in individual birds ranged over almost 4 orders of magnitude. The lowest levels were found in owl brain, while the highest levels were measured in sparrowhawk liver (up to $600 \mathrm{\mu g} \mathrm{kg}^{-1}$ wet weight), and differences observed between the different species could be related to differences in their diets. BB153 was also found in almost all samples, with a distribution similar to that of the BDEs. The highest levels of BB153 were measured in sparrowhawk liver (4.6 $\mathrm{gg} \mathrm{kg}^{-1}$ wet weight). No significant differences in BDE profiles were observed between different tissues of birds of the same species. However, significant congener profile differences were observed between the three species, suggesting different metabolic capabilities. The contribution of BDE47 and BDE183 to $\Sigma$ BDE was similar for the three species, whilst BDE153 was more prominent in owl, followed by buzzard and sparrowhawk. An inverse trend was seen for BDE100. BDE209 was also determined in these samples, but was deteced in only 6 liver samples (Voorspoels, unpublished data).

D’Silva et al. (2004) have determined16 BDE congeners (BDE17, BDE28, BDE47, BDE49, BDE66, BDE71, BDE77, BDE85, BDE99, BDE100, BDE119, BDE126, BDE138, BDE153, BDE154 and BDE183) in eggs and adipose tissue of herons (Ardea cinerea) collected from three UK sites in 2002-2003. BDEs were detected in all samples, and concentrations were typically higher in adipose tissue than in eggs from the same location. The percentage contribution of the more highly brominated congeners (hexaand heptabrominated) was higher in the eggs than in the corresponding tissue sample (ca. $20 \%$ and ca. $11 \%$, respectively). Congener profiles were similar to those reported previously for cormorant livers from the UK (Law et al., 2002), with BDE47 the dominant congener contributing $40-50 \%$ of $\Sigma$ BDE. $\Sigma$ BDE concentrations in adipose tissue ranged from 1,400 to 2,900 $\mu \mathrm{g} \mathrm{kg}^{-1}$ lipid, and the highest concentration observed in eggs was $4,100 \mu \mathrm{kg}^{-1}$ lipid.

Sinkkonen et al. (2004) determined methoxy tri-, tetra- and penta-BDE congeners in guillemots (whole animal) from the Baltic sea and Norwegian west coast using GC-EIMS. The tri- and penta-BDE congeners were not detected, but three MeO-TeBDE congeners were found in one Baltic guillemot sample, at concentrations ranging from 8.3 to 1,100 ng 
$\mathrm{kg}^{-1}$ lipid weight. The profile was similar to that observed previously in a Baltic salmon sample (Haglund et al., 1997). Seven BDE congeners (BDE15, BDE28, BDE47, BDE66, BDE99, BDE100 and BDE153) were also determined, and the concentrations of $\mathrm{BDE}$ and BDE47 in the same sample were 332 and $275 \mu \mathrm{g} \mathrm{kg}^{-1}$ lipid weight, respectively. Lower concentrations (118 and $82 \mu \mathrm{g} \mathrm{kg}^{-1}$ lipid weight) were seen in the Atlantic guillemot. The origin of MeO-BDEs in biological samples is unknown. They are often present in high concentrations relative to the BDEs themselves, although they are not known to be produced commercially and some may occur as natural products in marine environments (Gribble, 2000).

Götsch et al. (2004) determined polybrominated biphenyls in the egg of a white-tailed sea eagle on an enantioselective basis using GC-EIMS/MS. The level of contamination of BBs in Norwegian predatory bird eggs was low in comparison with that of BDEs. BB153 is usually the most prominent congener, and in this egg sample its concentration was 10 $\mu \mathrm{g} \mathrm{kg}{ }^{-1}$ wet weight. Of the atropisomeric BB congeners, only BB132 and BB149 were present at significant concentrations, although still $<1 \mu \mathrm{gg}^{-1}$ wet weight. For BB132, the enantiomeric ratio (ER) was 0.9, not significantly different from 1 . For BB149, the ER was in the range 0.68-0.72 $(n=3)$, indicating significant enantioselective enrichment.

\subsection{Fish, shellfish and benthic invertebrates}

The western Scheldt estuary is subject to a variety of suspected PBDE sources, such as a brominated flame retardant manufacturing plant, Antwerp harbour, and the textile industry located further upstream. BDE concentrations in samples of biota, including crab, shrimp, starfish, benthic fish (such as dab, goby, plaice and sole) and gadoid fish (such as bib and whiting) from the Scheldt Estuary were compared to those in samples from the Belgian North Sea beyond the mouth of the estuary (Voorspoels et al., 2003). Eight BDE congeners (BDE28, BDE47, BDE99, BDE100, BDE153, BDE154, BDE183 and BDE209) were determined. Concentrations observed in the Scheldt Estuary samples were up to 30 times higher than in those from the Belgian North Sea, with an increasing gradient towards Antwerp. Concentrations in the North Sea samples ranged from 0.02 to $1.5 \mu \mathrm{g} \mathrm{kg}$ wet weight in benthic invertebrates and goby, from 0.06 to $0.94 \mu \mathrm{g} \mathrm{kg}^{-1}$ wet weight in fish muscle, and from 0.84 to $128 \mathrm{\mu g} \mathrm{kg}^{-1}$ wet weight in fish liver. The corresponding ranges in samples from the Scheldt Estuary were from 0.2 to 30, 0.08 to 6.9, and from 15 to $984 \mu \mathrm{gg}^{-1}$ wet weight, respectively. BDE209 was only detected in 8 Scheldt Estuary liver samples (of bib, sole and whiting), at concentrations ranging from 3.4 to $37 \mu \mathrm{g} \mathrm{kg}^{-1}$ wet weight. The ratio BDE99/BDE100 was found to be highly locationand species-dependent, possibly relating to differences in metabolism. In shrimp, the value of this ratio (4:1) was very similar to that observed in the Bromkal formulation and in Scheldt Estuary sediment, and was similar in shrimp from both the Belgian North Sea and the Scheldt Estuary, implying both that these congeners are readily bioavailable and that shrimp lack the ability to metabolise either congener. BDE183 was not detected in any of the samples. On a lipid weight basis, concentrations of BDE47 ranged from 3 to $108 \mu \mathrm{g} \mathrm{kg}^{-1}$ lipid weight in samples from the Belgian North Sea, and from 8 to 1,550 $\mu \mathrm{g}$ 
$\mathrm{kg}^{-1}$ lipid weight in Scheldt Estuary samples. BDE47 was the most abundant congener in all samples, comprising 43 to $75 \%$ of $\Sigma$ BDE.

Covaci et al. (2002b) determined seven BDE congeners (BDE28, BDE47, BDE99, BDE100, BDE153, BDE154 and BDE183) in fish from the Danube Delta, a large wetland in Romania. $\Sigma$ BDE concentrations in eleven species of fish ranged from $<0.1$ to $14 \mu \mathrm{g}$ $\mathrm{kg}^{-1}$ lipid weight. There was no clear relationship between feeding pattern (benthic, herbivorous, omnivorous or piscivorous), but the highest concentrations were seen in carp. The $\Sigma$ BDE concentrations in sediments from the same locations as those at which fish were collected were $<0.1 \mu \mathrm{gg}^{-1}$ dry weight, while $\Sigma$ BDE levels between 2.9 and $6.5 \mu \mathrm{g}$ $\mathrm{kg}^{-1}$ lipid weight were found in cormorant liver.

The same seven BDE congeners were determined in large (2 to $6 \mathrm{~kg}$ weight) brown trout (Salmo trutta) from five lakes in SE Norway (Mariussen et al., 2003). The mean $\Sigma$ BDE concentrations in trout from Lake Mjøsa were much higher than in those from the other four lakes, $353 \mu \mathrm{g} \mathrm{kg}^{-1}$ wet weight compared to 3.6 to $18 \mu \mathrm{g} \mathrm{kg}^{-1}$ wet weight in trout from the other lakes (equivalent to 5,280 and 161 to $616 \mathrm{~g} \mathrm{~kg}^{-1}$ on a lipid basis). The highest $\Sigma$ BDE concentration observed was $1,120 \mu \mathrm{g} \mathrm{kg}^{-1}$ wet weight $\left(17,400 \mu \mathrm{g} \mathrm{kg}^{-1}\right.$ on a lipid basis). In whole-body homogenates of burbot (Lota lota), $\mathrm{BDDE}$ concentrations up to $2,270 \mu \mathrm{g} \mathrm{kg}^{-1}$ wet weight (45,100 $\mu \mathrm{g} \mathrm{kg}^{-1}$ on a lipid basis) were observed. Lake Mjøsa is located in a relatively densely populated and industrialised area, and the study suggests that there is a local source of congeners deriving from the commercial penta-mix formulation. HBCD was detected in fish of a number of species from Lake Mjøsa and further downstream at concentrations from 90 to $800 \mu \mathrm{g} \mathrm{kg}^{-1}$ lipid (Schlabach et al., 2004). The profiles were dominated by $\alpha-\mathrm{HBCD}$, as in other studies.

Allchin and Morris (2003) determined HBCD (by LC-MS) and BDEs (BDE28, BDE47, BDE99, BDE100, BDE153 and BDE154) in edible fish (brown trout and eel Anguilla anguilla) from the Rivers Skerne and Tees in NE England, downstream of a brominated flame retardant manufacturing plant. BDEs were detected in fish from all sites, and the lowest concentrations were found in the two upstream Tees sites above the Skerne confluence. Mean $\Sigma$ BDE concentrations in trout at these sites were 4.9 and $5.3 \mu \mathrm{g} \mathrm{kg}^{-1}$ wet weight. The highest concentrations (mean and maximum $\Sigma$ BDE concentrations 118 and $197 \mu \mathrm{g} \mathrm{kg}^{-1}$ wet weight) were observed just downstream of the factory in which PBDE formulations had previously been manufactured (Allchin et al., 1999), and declined with distance downstream to $23 \mu \mathrm{gg}^{-1}$ wet weight at Croft-on-Tees, below which trout could not be caught. Mean $\Sigma$ BDE concentrations in eels sampled at 4 sites further downstream in the River Tees, as far as the tidal barrage, ranged from 130 to $235 \mu \mathrm{g} \mathrm{kg}^{-1}$ wet weight. The congener profiles, in which BDE47 dominated, reflected exposure primarily to pentamix congeners. Despite the cessation of production of PBDE formulations in the late1990s, BDE concentrations remain high in edible fish from the Rivers Skerne and Tees. The results of this study are in line with the earlier studies which indicated widespread contamination of the Rivers Skerne and Tees, Tees Bay, and the western North Sea with 
BDEs (Allchin et al., 1999; Allchin and de Boer, 2001; de Boer and Allchin, 2001; Boon et al., 2002).

HBCD was detected in all samples with a similar distribution pattern to that of the BDEs. In trout at the two upstream Tees sites, $\Sigma$ HBCD concentrations were 20 and $26 \mu \mathrm{gg}^{-1}$ wet weight, 4 to 5 times higher than the $\Sigma \mathrm{BDE}$ concentrations at the same locations. Very high concentrations were found in trout from Haughton Road, downstream of the plant then manufacturing HBCD, with a mean concentrations of 2,340 $\mu \mathrm{g} \mathrm{kg}^{-1}$ wet weight and values up to $6,760 \mu \mathrm{g} \mathrm{kg}^{-1}$ wet weight in individual fish. Again, concentrations in eels sampled further downstream were even higher, with mean concentrations up to 3,220 $\mu \mathrm{g}$ $\mathrm{kg}^{-1}$ wet weight and individual values exceeding $10,000 \mu \mathrm{gg}^{-1}$ wet weight. The diastereomer profile was dominated by the $\alpha$-isomer, in contrast with that in sediments where the $\gamma$-diastereomer is dominant, as described above.

Concentrations of $\Sigma$ HBCD in herring (Clupea harengus) muscle collected from Sweden in 1999-2000 ranged from 21 to $26 \mu \mathrm{g} \mathrm{kg}^{-1}$ lipid on the west coast and 34 to $180 \mu \mathrm{g} \mathrm{kg}^{-1}$ lipid weight in the Baltic Sea (Remberger et al., 2004). In the same study, homogenates of pike and eel collected upstream and downstream of industrial effluents showed HBCD concentrations, determined using GC-EIMS, of 120 and 970 and 65 and 1,800 $\mu \mathrm{g} \mathrm{kg}^{-1} \mathrm{dry}$ weight, respectively.

Asplund et al (2004) investigated spatial and temporal trends of BDEs, MeO-BDEs and HBCD in herring from the Swedish coast using GC-ECNIMS. The BDE congeners determined were BDE47, BDE99, BDE100, BDE153 and BDE154; and the methoxylated derivatives studied were 6-MeO-BDE47 and 2'-MeO-BDE68. No significant time trends were apparent for any of the compounds determined, and it seems likely that the MeOBDEs are of natural origin. HBCD showed a strong regional differentiation, with higher concentrations in fish from the southern Baltic Sea. Concentrations of BDE47 (the dominant congener) were similar in fish from both the Baltic and North Seas. This is in contrast to the situation for PCBs, for which concentrations are about five times higher in the Baltic, and suggests that the sources and inputs of these two groups of chemicals are quite different.

Eljarrat et al. (2004b) determined HBCD (by GC-ECNIMS) and BDEs (40 congeners, but only 16 detected) in barbel (Barbus graellsi) from 4 sites in the Cinca River, NE Spain, a tributary of the River Ebro. HBCD was detected at concentrations of not detected to 625 and not detected to $750 \mu \mathrm{g} \mathrm{kg}^{-1}$ wet weight in liver and muscle tissue, respectively. Detection limits for HBCD in fish tissues were within the range 0.002 to $0.019 \mathrm{~kg}^{-1}$ wet weight. $\Sigma$ BDE concentrations ranged from 0.2 to 279 and 1.3 to $298 \mu \mathrm{g} \mathrm{kg}^{-1}$ wet weight in the same tissues. BDE209 was not detected, but BDE183 was found in both tissues at concentrations up to $59 \mu \mathrm{g} \mathrm{kg}^{-1}$ in muscle and $70 \mu \mathrm{g} \mathrm{kg}^{-1}$ in liver. The congener profile was dominated in most cases by BDE153 and BDE154, and BDE47 was always a minor component. Eljarrat et al. (2004c) also determined HBCD (by GC-ECNIMS) and BDEs (BDE47, BDE153, BDE154, BDE183 and BDE209) in bleak (Alburnus alburnus) from 3 
sites in the Cinca River. HBCD was detected in whole fish at concentrations from 2 sites at concentrations from 73 to $1,640 \mu \mathrm{gg}^{-1}$ wet weight, and was not detected at the third site. BDE209 was not detected in any of the fish analysed, but BDE183 was found at concentrations from not detected to $52 \mu \mathrm{g} \mathrm{kg}^{-1}$ wet weight. As for the barbel from the same area, the congener profile from the two most contaminated sites was dominated by BDE153 and BDE154, and BDE47 was a minor component. The authors conjectured that this may reflect the use of the octa-mix PBDE formulation in this area, which includes a heavily industrialized town, Monzón.

Morris et al. (2004) determined HBCD and TBBP-A using LC-MS in fish, eels and benthic invertebrates from locations in the UK and the Netherlands. $\Sigma$ HBCD concentrations in seastars from the western Scheldt were in the range $<30$ to $84 \mu \mathrm{g} \mathrm{kg}^{-1}$ lipid weight, and the range in common whelks from the North Sea was 29 to $47 \mu \mathrm{gg}^{-1}$ lipid weight. In eels from The Netherlands, $\Sigma$ HBCD concentrations ranged from $<0.6$ to $93 \mu \mathrm{gg}^{-1}$ lipid weight, and concentrations in a similar range were found in cod, hake and whiting. In cormorant liver, common tern eggs, harbour seal blubber and harbour porpoise blubber, $\Sigma$ HBCD concentrations ranged from 138 to 1320, 330 to 7100, 63 to 2060 and 440 to $6800 \mathrm{\mu g} \mathrm{kg}^{-1}$ lipid weight, respectively. As for BDEs, therefore, the major increase in HBCD concentrations appears at the transition from gill-breathing to lung-breathing animals. Concentrations of TBBP-A in the seastars were in the range $<1$ to $2 \mu \mathrm{g} \mathrm{kg}$ lipid weight, and in whelks ranged from 5.0 to $96 \mu \mathrm{g} \mathrm{kg}^{-1}$ lipid weight. In eels and fish, concentrations ranged from $<0.2$ to $245 \mu \mathrm{g} \mathrm{kg}^{-1}$ lipid weight, and in cormorant liver and harbour porpoise blubber ranged from 2.5 to 14 and 0.1 to $418 \mu \mathrm{g} \mathrm{kg}^{-1}$ lipid weight, respectively. TBBP-A was not detected in single samples of common tern eggs or harbour seal blubber. TBBP-A therefore seems to be less bioaccumulative than HBCD, due either to its more polar nature or more ready metabolism.

Polar cod (Boreogadus saida)from Svalbard (Wolkers et al., 2004) yielded a geometric mean BDE47 concentration of $2.1 \mu \mathrm{g} \mathrm{kg}^{-1}$ lipid weight, with BDE47 representing ca. 60\% of $\Sigma \mathrm{BDE}$ (22 congeners). Spatial and temporal trends of BDEs (congeners BDE28, BDE47, BDE100 and BDE154) and HBCD were studied in polar cod and Atlantic cod from Norwegian waters (Bytingsvik et al., 2004). Polar cod were collected from Bear Island, and Atlantic cod at two sites in south (Hvaler) and central (Froan) Norway in 2003. Cod from Hvaler taken in 1998 were also available for analysis. Concentrations of all compounds determined decreased in the order Hvaler $>$ Froan $>$ Bear Island in 2003. At Hvaler, an increase of $3-4$ times was seen in wet weight concentrations of all BDE congeners over the period 1998-2003, and an eightfold increase for HBCD. On a lipid weight basis the increases were more modest, 1.5 times and 3 to 4 fold, respectively.

Trout (3 species) from 11 high mountain lakes in Europe (566 to 2,485m altitude) were taken for BDE analysis (Vives et al., 2004). These lakes were selected as being far from local pollution emission sources, and it was considered that the only source of BDEs to 
these lakes was as a result of atmospheric transport and deposition. The major congeners identified (of 39 determined) were BDE47 and BDE99, followed by BDE100, BDE153, BDE154 and BDE28, and these congeners were found in all samples analysed $(\mathrm{n}=51)$. The highest concentrations of $\Sigma \mathrm{BDE}$ in fish muscle and liver were found in Lochnagar, Scotland, 1.2 and $11 \mu \mathrm{g} \mathrm{kg}-1$ wet weight, respectively (177 and $366 \mu \mathrm{gg} \mathrm{kg}^{-1}$ on a lipid basis). This could suggest higher BDE emissions in the UK than in other countries, as a result of production and use. No correlation was observed between the occurrence of these compounds and altitude, latitude or temperature, and the authors inferred that the environmental distribution of the BDEs has not, as yet, reached a steady-state.

Hydroxylated BDEs (OH-BDEs) have been detected and identified as metabolites in several species after exposure to specific BDE congeners but have also been found to occur as natural products in marine sponges and ascidians (Marsh et al., 2004).

Methoxylated BDEs (MeO-BDEs) have also been reported as natural products present in marine sponges and green algae. Thus, the origin of these substances can be natural, anthropogenic or both. Nine OH-BDEs and six MeO-BDEs were identified in Baltic Sea salmon (Salmo salar) blood using newly synthesized standards (Marsh et al., 2004). All of the identified $\mathrm{OH}$ - and $\mathrm{MeO}-\mathrm{BDEs}$ were substituted with four or five bromine atoms and five also had one chlorine substituent. Fourteen have the methoxy or hydroxy group substituted in the ortho- position to the diphenyl ether bond. The structures of several of the compounds support natural rather than anthropogenic origins. However, at least one of the OH-BDEs (4'-OH-BDE49) may be a hydroxylated metabolite of BDE47.

Temporal trends of concentrations of BDE47, BDE99, BDE100, BDE153 and BDE154, as well as of two MeO-BDE congeners (6-MeO-BDE47 and 2'-MeO-BDE68) were determined in pike from Lake Bolmen, Sweden, during the years 1967-2000 (Kierkegaard et al., 2004a). All of the BDE congeners showed increasing trends in concentrations up to the mid-1980s, with a more than 25-fold increase during this period (from 60 to $1600 \mathrm{ng}$ $\mathrm{kg}^{-1}$ wet weight in 1989). After the mid-1980s, the concentrations either levelled off or began to decrease. The decreases of concentrations in pike are much slower than has been seen for guillemots in the Baltic Sea (Sellström et al., 2003)suggesting that there are local sources of BDEs close to Lake Bolmen. For the MeO-BDEs, the concentrations decline during the same period, with the decline for 6-MeO-BDE47 continuing into the 1990s. No correlation was seen between the BDE concentrations and the MeO-BDE concentrations, indicating other sources than the BDEs for the MeO-BDE compounds.

MeO-BDE congeners (tri-, tetra- and penta-BDEs) were also determined in Baltic Salmon and Arctic cod (Gadus morhua) (Sinkkonen et al., 2004). The tri- and penta-BDE congeners were not detected, but three MeO-TeBDE congeners were detected in Baltic salmon, and two in cod. Concentrations of those congeners detected ranged from 22 to $5,710 \mathrm{ng} \mathrm{kg}^{-1}$ lipid weight in salmon and 14 to $16,400 \mathrm{ng} \mathrm{kg}^{-1}$ lipid weight in cod. The concentrations of MeO-TeBDEs in the Arctic cod liver samples from years 1992 and 1993 were higher than those seen in both earlier (1987-1991) and later (1994-1995, 1998) years. 
Livers from dab (Limanda limanda), and flounder (Plathychthis flesus) have been analysed for a range of BDE congeners (BDE28, BDE47, BDE66, BDE71, BDE75, BDE85, BDE99, BDE100, BDE138, BDE153, BDE154, BDE183, BDE190 and BDE209) (Lepom, unpublished data). With the exception of BDE71, BDE190 and BDE209, all congeners were found at detectable concentrations in at least some of the samples. $\Sigma \mathrm{BDE}$ concentrations (sum of the tri- to hexa-brominated congeners) in individual liver samples ranged from 1 to $26 \mu \mathrm{g} \mathrm{kg}^{-1}$ wet weight (mean 1.7 to 15.6) corresponding to 5 to $100 \mu \mathrm{g}$ $\mathrm{kg}^{-1}$ lipid weight (mean 7.5-70.9). BDE congener patterns in the two fish species were similar, with BDE47 as the dominant congener followed by BDE100 and BDE154. BDE99, vulnerable to metabolism in freshwater fish (Stapleton et al., 2004a) was found at much lower concentrations than would be expected from its percentage composition in the technical penta-mix formulation. This suggests that there are similar metabolic pathways for this congener in marine fish species. There were pronounced differences in liver BDE concentrations of flatfishes from various locations (Figure 2). Although the food of dab varies with local conditions, it eats any bottom-living invertebrate which is abundant locally and which is small enough to be captured (small crustacean, molluscs, polychaetes and other worms), the differences seen in BDE concentrations indicated geographical differences in the level of contamination. The highest BDE concentrations were found in the central North Sea (station P01) near a Danish oil and gas production area (Danfield) and off the British coast (stations N04, N06). The lowest BDE concentrations were seen in dab and flounder from the Baltic Sea (stations B1, B11). Voorspoels et al. (2003) reported BDE concentrations in dab liver from the Western Scheldt Estuary (a highly polluted estuary) and from the Belgian North Sea which were in the same order of magnitude as those from sampling sites near the British coast and at Danfield. The Tees estuary has previously been shown to be a major source of BDE congeners deriving from the penta-mix formulation to the North Sea (Boon et al., 2002) , but in the light of the data reported here the Danish gas and oil production area has also to be considered as a possible major source of tri- to hexa-BDE congeners to the central North Sea. Lipidnormalised BDE47 concentrations in cod (Gadus morhua) liver samples taken at three sites (N04, B01, B11) ranged from 14 to $35 \mu \mathrm{gg}^{-1}$ and were much lower than those reported in previous studies in cod from the North Sea (de Boer, 1989; de Boer and Allchin, 2001; Boon et al., 2002). There were no marked differences in BDE levels in cod from the three locations.

Paepke and Herrmann (2004) determined BDEs (congeners BDE17, BDE28, BDE47, BDE66, BDE77, BDE99, BDE100, BDE153, BDE154, BDE183 and BDE209) in fish from the North Sea (herring, Clupea harengus) and the North-east Atlantic (plaice, Pleuronectes platessa; trout, Salmo trutta; and halibut, Hippoglossus hippoglossus) using GC-HRMS. The fish were bought from markets in Germany. $\Sigma$ BDE concentrations in fish muscle were $14,6.7,9.7$ and $0.4 \mu \mathrm{g} \mathrm{kg}^{-1}$, respectively, expressed on a lipid basis. Hites et al. (2004a) determined BDEs (43 congeners) in wild and farmed salmon collected around the world. $\Sigma$ BDE concentrations were significantly higher in farmed salmon from Europe (especially Scotland) than in those from North America and Chile, and than those in wild salmon, up to ca. $5 \mu \mathrm{g} \mathrm{kg}$-1 wet weight, similar to concentrations reported earlier by 
Jacobs et al. (2002). The congener profiles were dominated by BDE47, then BDE99 and BDE100. Bethune et al. (2004) determined BDEs (congeners 28, BDE47, BDE99, BDE100, BDE153 and BDE154) in fish (salmon, mackerel Scomber scombrus, herring, cod and halibut), blue mussels and edible crabs Cancer pagurus from Norway collected in 2003. Analysis was by GC-ECNIMS. $\Sigma$ BDE concentrations ranged from 1.1 to $4.5 \mu \mathrm{g}$ $\mathrm{kg}^{-1}$ wet weight in salmon, 1.3 to $1.8 \mu \mathrm{g} \mathrm{kg}$-1 wet weight in mackerel, 1.0 to $3.5 \mu \mathrm{gg} \mathrm{kg}^{-1}$ wet weight in herring, 0.3 to $18 \mu \mathrm{g} \mathrm{kg}^{-1}$ wet weight in halibut and 0.02 to $0.04 \mu \mathrm{g} \mathrm{kg}^{-1}$ wet weight in cod, all samples being of muscle. Cod liver contained 5.2 to $9.5 \mu \mathrm{g} \mathrm{kg}^{-1}$ wet weight. Crab muscle contained 0.03 to $0.07 \mu \mathrm{g} \mathrm{kg}^{-1}$ wet weight, and shell meat 0.6 to 7.0 $\mu \mathrm{g} \mathrm{kg}{ }^{-1}$ wet weight. $\Sigma$ BDE concentrations in blue mussels were 0.06 to $0.25 \mu \mathrm{gg}^{-1}$ wet weight. BDE47 accounted for 60-70\% of $\Sigma$ BDE, and BDE99 and BDE100 were the next most abundant congeners.

Zennegg et al. (2003) determined BDEs (BDE28, BDE47, BDE99, BDE100, BDE153, BDE154 and BDE183) in whitefish (Coregonus sp.) collected from eight lakes and farmed rainbow trout (Oncorhynchus mykiss) from four fish-farms in Switzerland. In whitefish muscle, $\Sigma$ BDE concentrations ranged from 2.0 to $7.4 \mu \mathrm{g} \mathrm{kg}{ }^{-1}$ wet weight (36 to $165 \mu \mathrm{g} \mathrm{kg}^{-1}$ on a lipid basis). The highest concentration was found in Lake Greifen, and the lowest in Lake Thun. A similar congener pattern was observed for all samples, dominated by BDE47 and followed by BDE99 and BDE100. BDE183 was found in trace amounts, 0.06 to $0.2 \mu \mathrm{g} \mathrm{kg}^{-1}$ lipid weight. All of the lakes investigated are situated in populated areas and, although none can be considered as background sites, diffuse contamination and atmospheric deposition are the most likely source for the BDEs found in whitefish. Lower $\Sigma \mathrm{BDE}$ concentrations were found in the farmed trout, from 0.7 to 1.3 $\mu \mathrm{gg}^{-1}$ wet weight (12 to $24 \mu \mathrm{g} \mathrm{kg}^{-1}$ on a lipid basis). HBCD was also determined in whitefish from six Swiss lakes using LC-MS (Gerecke et al., 2003). As in other studies of biota, $\alpha$-HBCD dominated the profile although $\gamma$-HBCD is the predominant diastereomer in the technical product. $\Sigma$ HBCD concentrations ranged from 25 to $210 \mu \mathrm{g} \mathrm{kg}^{-1}$ lipid weight ( $n=6$; analysis using GC), and $\alpha$-HBCD concentrations $(n=4)$ ranged from 54 to $210 \mu \mathrm{g} \mathrm{kg}^{-1}$ lipid weight. The $\beta$ - and $\gamma$-diastereomers were not detected.

Magnusson et al. (2003) spiked intact, soft-bottom sediments with ${ }^{14} \mathrm{C}$-labelled BDE47, and studied the vertical distribution of the compound within the sediment and its bioaccumulation in 39 different macrofauna taxa over 29 weeks exposure. Throughout the period, $90 \%$ of the BDE47-derived radioactivity was observed in the upper $5 \mathrm{~cm}$ of the sediment, mixed to that depth by bioturbation. Biota-sediment accumulation factors (BSAFs) were significantly higher for surface deposit feeders than for the suspension feeders, subsurface deposit feeders and predators, which yielded similar BSAF values to one another. Trophic level in the foodweb, measured as ${ }^{15} \mathrm{~N}$ enrichment, was not correlated with the degree of bioaccumulation. Hydrophilic metabolites of BDE47 were found in 15 of the species studied, indicating that biotransformation had taken place.

Johansson et al. (2004, in press 2005) determined BDEs (congeners BDE28, BDE47, BDE49, BDE66, BDE77, BDE85, BDE99, BDE100, BDE138, BDE153, BDE154, 
BDE183 and BDE209) in archived, freeze-dried, blue mussel samples from the Seine estuary, France, using GC-ECNIMS. Over the period 1982 to 1993, there was an exponential increase in BDE concentrations. Between 1993 and 1997 levels were constant, followed by a further increase to a maximum in 1999 and 2001 (peak EBDE concentration $24 \mu \mathrm{g} \mathrm{kg}^{-1}$ dry weight), and by a significant decline after 2002 (Figure 3). If this decline has resulted from the reduction in the usage of the penta-mix PBDE formulation in Europe, then it has occurred much more rapidly than that for PCBs following their earlier prohibition.

BDE analyses of zebra mussels (Dreissena polymorpha) were included in a larger study undertaken in and around the city of Stockholm, Sweden (Lithner et al., 2003). Mussels were collected from a background site (Stäket, northern inflow to Lake Mälaren) and transplanted in baskets to other downstream sites in Lake Mälaren (west side of Stockholm at Riddarfjärden), Saltsjön (east side of Stockholm in Saltsjön) and in several small lakes. Freshwater flows from Lake Mälaren, through the middle of Stockholm, then out into the brackish Baltic Sea via Saltsjön. Five BDE congeners (BDE47, BDE99, BDE100, BDE153 and BDE154) were determined. $\Sigma$ BDE concentrations were low and ranged from 0.4 to $0.79 \mu \mathrm{g} \mathrm{kg}^{-1}$ wet weight (19 to $39 \mu \mathrm{g} \mathrm{kg}^{-1}$ lipid weight). The congener pattern was dominated by BDE47 and BDE99 and was similar to the penta-mix PBDE technical product. Comparison on a lipid weight basis showed that BDE concentrations were higher close to Stockholm than at the background site and that there was no difference between concentrations on the west or east side of the city centre.

Bioaccumulation factors (BAFs) for the various compounds studied were estimated using data from suspended particulate matter (SPM) collected in sediment traps in 1998-99 at the same sites in Riddarfjärden and Saltsjön (Broman et al., 2001). The concentrations on SPM were assumed to reflect water concentrations. BAFs were calculated using lipid weight concentrations in mussels and organic carbon based concentrations in the SPM as a surrogate for water concentrations. When compared to other compounds (PCBs, DDTs, $\mathrm{HCB}$ ), the BDEs had the highest BAFs, ranging from 1 to 2 . The highest BAF value obtained was for BDE154 and lowest was for BDE47. In other compound groups studied, BAFs ranged from 0.1 ( $p, p$ '-DDD) to 0.5 (CB153). This is in agreement with other studies in blue mussels showing higher bioaccumulation potential for the lower brominated BDEs when compared to CBs with similar octanol-water partition coefficients (Gustafsson et al., 1999; Booij et al., 2002).

Gama et al. (2004) determined BDEs (congeners BDE28, BDE47, BDE66, BDE71, BDE75, BDE77, BDE85, BDE99, BDE100, BDE119, BDE138, BDE153, BDE154, and BDE190) in riverine fish (Barbus spp.) and coastal mussels (Mytilus galloprovincialis) from Portugal using GC-ECNIMS. Lower concentrations were observed in mussels than fish. For BDE47, the concentration in mussels was approximately $2 \mu \mathrm{g} \mathrm{kg}^{-1}$ dry weight, whilst in fish muscle and liver the ranges were not detected to $7.9 \mu \mathrm{g} \mathrm{kg}^{-1}$ dry weight and 1.6 to $30 \mu \mathrm{g} \mathrm{kg}{ }^{-1}$ dry weight, respectively. 
Covaci et al. (2004) have investigated the levels and distribution of BDEs (congeners BDE28, BDE47, BDE49, BDE66, BDE85, BDE99, BDE100, BDE153, BDE154 and BDE183) in zebra mussels and several freshwater fish species (eel, carp and gibel carp Carassius gibelio) at various sites in Flanders, Belgium. At most sites, individual BDE congeners were present at detectable levels in whole zebra mussel tissue, with $\Sigma$ BDE concentrations ranging from 0.15 to $1.8 \mu \mathrm{g} \mathrm{kg}^{-1}$ wet weight. Except for one site (Blokkersdijk, Antwerp), where sum BDEs was $<0.1 \mu \mathrm{g} \mathrm{kg}^{-1}$ wet weight in carp muscle, all fish samples from other sites contained detectable levels of BDEs, with the highest concentrations (14 $\pm 14 \mu \mathrm{g} \mathrm{kg}^{-1}$ wet weight) being measured in eel liver from Watersportbaan (Ghent). The sampled sites covered a broad concentration range of organohalogenated pollutants with the highest values consistently found in eel liver. Generally, correlations between concentrations of BDEs and of CBs, HCB and $p, p$ '-DDE for each species were low $(r<0.50)$ and most were not statistically significant $(p>0.05)$.

\subsection{Baltic Sea/Atlantic Ocean Food Chains}

Studies of the biomagnification of tri- to deca -BDEs were carried out in three different food chains, two in the Baltic Sea (roach (Rutilus rutilus), perch (Perca fluviatilis), pike (Esox lucius) (Burreau et al., 2004); zooplankton, sprat (Sprattus sprattus), herring, salmon) and one in the Atlantic Ocean (zooplankton, small herring, large herring, salmon) (Burreau, 2001). Samples were analysed for 13 BDE congeners (BDE28, BDE35, BDE47, BDE49, BDE66, BDE99, BDE100, BDE153, BDE154, BDE155, BDE183, BDE203 and BDE209) as well as stable nitrogen isotopes. In addition, an unknown hepta-BDE (Hp1) and three unknown nona-BDEs (No1, No2, No3) were detected and quantified.

\subsection{Roach, perch, pike food chain in the Baltic Sea}

When compared on a lipid weight basis, BDE47 was the major congener found in perch (median: $10 \mu \mathrm{g} \mathrm{kg}^{-1}$ lipid weight) and pike (71 $\mu \mathrm{g} \mathrm{kg}^{-1}$ lipid weight) (Burreau et al., 2004). However, the major congener found in the omnivorous roach was BDE209 (48 $\mathrm{ug} \mathrm{kg}^{-1}$ lipid weight), and the median BDE99 concentration was particularly low in roach. Low BDE99 levels have been seen previously in several other fish species (bream, carp) (Sellström et al., 1993; Dodder et al., 2002; Stapleton et al., 2004a) and indicate significant metabolism of this congener.

Roach have higher concentrations of the three NoBDEs, as well as BDE209, than those seen in perch and pike. This may be related to their association with sediments, which are known to have generally higher concentrations of BDE209 than the lower brominated congeners and the fact that BDE209 has been shown to be bioavailable from the fish gut (Kierkegaard et al., 1999; Tomy et al., 2004). Regression analyses between lognormalised concentrations of each BDE congener and the $\delta^{15} \mathrm{~N}$ values were used to study food chain biomagnification. 
Biomagnification was described using the following equation

$C=A \cdot \mathrm{e}^{(\mathrm{B} \cdot \delta 15 \mathrm{~N})}$

where $c$ is the concentration of a substance measured in organisms in which $\delta^{15} \mathrm{~N}$ is also measured. The term $A$ is a constant and the $\mathrm{B}$ value describes the biomagnification potential of a substance. A positive $B$ value means that the concentration of a certain substance is higher at a higher trophic level and that biomagnification has occurred.

All the tri- to hepta-BDE congeners biomagnified, but showed a maximum biomagnification for the penta-BDEs ( $\log \mathrm{K}_{\mathrm{ow}}$ values 7.24 - 7.32). The biomagnification of the hexa- and hepta-BDEs was negatively correlated with the degree of bromination, probably due either to large molecular size or high molecular weight. Although the octaand nona- BDEs and BDE209 did not biomagnify, they were detected in several of the species, indicating that they are bioavailable. Interestingly, the B values for the BDE congeners that biomagnify were much higher $(0.5$ - 0.9) than those of chlorobiphenyls (0.3 - 0.5) of similar hydrophobicity.

5.5 Zooplankton, sprat, herring, salmon in the Baltic Sea and comparison to the Atlantic Ocean food chain (zooplankton, small herring, large herring, salmon)

When compared on a lipid weight basis, BDE47 was the major congener found in zooplankton (median: $2.3 \mu \mathrm{g} \mathrm{kg}^{-1}$ lipid weight), sprat (3 $\mu \mathrm{g} \mathrm{kg}^{-1}$ lipid weight), herring (4.5 $\mu \mathrm{gg}^{-1}$ lipid weight) and salmon (22 $\mathrm{g} \mathrm{kg}^{-1}$ lipid weight) (Burreau, 2001). However, the BDE209 concentration in zooplankton was comparable $\left(2.1 \mathrm{\mu g} \mathrm{kg}^{-1}\right.$ lipid weight) to that of BDE47. BDE209 was present, but at much lower concentrations, in all three fish species (0.082 to $0.41 \mu \mathrm{g} \mathrm{kg}{ }^{-1}$ lipid weight).

As for the roach, perch, pike food chain, the tri- to hepta-BDEs biomagnified, again showing maximum biomagnification for the penta-BDEs. As in the previous case, the biomagnification of the hexa- and hepta-BDEs was negatively correlated with the degree of bromination. Although the octa- and nona- BDEs and BDE209 did not biomagnify in the entire food chain, they were found in several of the species, indicating that they are bioavailable. When zooplankton are excluded, BDE209 concentrations do increase with trophic level in the fish species, with biomagnification factors of 2.9 for herring/sprat and 1.7 for salmon/herring. The B values for the BDE congeners that biomagnify were similar (0.4) to those of CBs $(0.3-0.4)$ of similar hydrophobicity. Higher BDE concentrations were found in the Baltic Sea fish than in the Atlantic fish. Biomagnification was more difficult to discern in the Atlantic Ocean food chain due to confounding body size effects in the fish.

\subsection{Common tern and harbour seal food chains}


Leonards et al. (2004) studied the transfer of BDEs (congeners BDE28, BDE47, BDE49, BDE66, BDE71, BDE75, BDE77, BDE85, BDE99, BDE100, BDE119, BDE138, BDE153, BDE154, BDE183, BDE190 and BDE209), and HBCD and TBBP-A, using GC-ECNIMS and LC-MS, respectively. The samples comprised sediment, suspended particulate material, invertebrates (e.g. bivalves, shrimps, worms), and fish (e.g. sandeeel, flounder, goby, sole, herring, whiting) collected in spring 2003 in the feeding habitats of the common tern (Sterna hirundo), the western Scheldt estuary, and harbour seals (Phoca vitulina), the Wadden Sea. Tern eggs were collected from the Terneuzen colony, and the blubber of adult male seals collected from stranded animals from the Wadden Sea population. In sediment and SPM, the dominant BFRs were BDE209 and HBCD, and in biota BDE47 and HBCD, followed by BDE49, BDE99, BDE100 and BDE154. For the common tern food chain, BDE concentrations expressed on a lipid basis increased from invertebrates to fish (sandeel) to tern. In contrast, HBCD concentrations increased from invertebrates to fish, but decreased from fish to tern eggs, which suggests that terns may be able to metabolise HBCD. In the tern eggs and fish the $\alpha$-HBCD diastereomer dominates, but the $\gamma$-HBCD diastereomer dominates in sediments and SPM, which is consistent with other studies. It is, however, unknown whether this is a result of selective uptake between the three diastereomers, conversion of the $\gamma$ - to the $\alpha$-diastereomer, or the result of selective metabolism. The first study of enantiomers of HBCD diastereomers using LC-MS/MS has recently been reported (Janak et al., 2004), and this approach may yield additional information in the future. Distribution, fate, toxicity and their environmental significance may be different for different enantiomers.

In the study by Leonards et al. (2004), BDE209 was found in 24\% of the fish samples analysed, at concentrations ranging from 1.9 to $17 \mu \mathrm{g} \mathrm{kg}^{-1}$ lipid weight. Three possible explanations were proposed :

1. sediment particles found in the intestines of the fish contribute to "whole" fish concentrations, as BDE209 was the dominant congener in sediment;

2. BDE209 is bound to the outside skin of the fish;

3. BDE209 is incorporated into the internal organs and tissues of the fish.

The authors were able to discount the first of these, but further analyses are needed before the others can be evaluated.

The BDE congener patterns in prey species, tern eggs and seal blubber suggest that tern are probably able to metabolise BDE49, which has vicinal H-atoms at the meta-para postion. They are unable, however, to metabolise BDEs which have vicinal $\mathrm{H}$-atoms at the ortho-meta position, such as BDE26, BDE66 and BDE75, in line with other bird species. Seals are able to metabolise both groups of congeners, as has been observed for chlorobiphenyls (Boon et al., 1997), and hence have a greater metabolic capacity than terns.

\subsection{Marine mammals}


Blubber biopsy and blood samples were collected from weaned grey seal (Halichoerus grypus) pups and juveniles during 1998 and 1999 (Hall et al., 2003). 54 post-weaned pups and 55 first year juveniles were studied, of which 13 were recaptured post-weaned pups. The median concentrations of $\Sigma$ BDE (14 congeners) were 0.17 and $0.46 \mu \mathrm{g} \mathrm{kg}^{-1}$ lipid weight in the blubber of the pups and the juveniles, respectively. The study indicated that thyroid hormone levels in the blood of grey seals during their first year of life were significantly, and positively, related to $\Sigma$ BDE concentrations in blubber, after accounting for the effects of possible confounding variables. Such an association is not, in itself, sufficient evidence for a causal relationship, but is in accordance with the hypothesis that these compounds can act as endocrine disrupters in grey seal pups. Morris et al. (2004) found that the diastereomeric profiles of HBCD in harbour seals and harbour porpoises were strongly dominated by the $\alpha$-HBCD isomer, which accounted for $>80 \%$ of $\Sigma$ HBCD. HBCD concentrations in liver and blubber of these species from the Wadden and North Seas were in the range 2.1 to $6.8 \mathrm{mg} \mathrm{kg}^{-1}$ lipid weight, though very few animals yielded positive values for TBBP-A.

Covaci et al. (2002c) determined a suite of BDE congeners (BDE28, BDE47, BDE66, BDE71, BDE99, BDE100, BDE153 and BDE154) in the liver of 21 harbour porpoises (Phocoena phocoena) stranded on the Belgian coast during 1997-2000. The range of $\Sigma$ BDE concentrations was 410 to $5,800 \mu \mathrm{g} \mathrm{kg}^{-1}$ lipid weight, with a mean value of 2,180 $\mu \mathrm{gg}^{-1}$. The median concentrations of BDEs were higher in the adult group $(\mathrm{n}=8)$ than in the juveniles $(n=13)$. The BDE profile was, as is common in marine mammals, dominated by BDE47, followed by BDE100, BDE99, BDE154 and BDE153.

Thron et al. (2004) determined BDEs (BDE17, BDE47, BDE49, BDE99, BDE100, BDE119, BDE140, BDE153, BDE154 and BDE183) in the blubber of harbour porpoises from Iceland, Norway, and the Baltic and North Seas collected between 1997-2001. The animals were either stranded or accidentally caught in gill-nets. $\Sigma$ BDE concentrations ranged widely, from 18 to 5,800 $\mu \mathrm{g} \mathrm{kg}^{-1}$ lipid weight. Animals with poor body condition (lower mean blubber thickness) had much higher concentrations, as did males, but no correlation with age was observed. However, females showed decreasing concentrations with age, indicating elimination via transfer from mother to offspring. When animals of similar age, sex and body condition were considered, the concentrations of BDEs were similar in the Baltic and North Sea areas (median $=170 \mu \mathrm{g} \mathrm{kg}^{-1}$ lipid weight) and were significantly higher than those in animals from Iceland (median $=38 \mu \mathrm{g} \mathrm{kg}^{-1}$ lipid weight). Also, BDE concentrations tended to decrease with increasing latitude along the Norwegian coast. The regional differences observed were attributed to the proximity to local sources of PBDEs in Europe.

Kalantzi et al. (2004 in press) tagged grey seal pups on the Farne Islands, NE England, during the 1998 and 1999 breeding seasons. Blubber biopsy samples collected at the same time were then analysed for BDEs (congeners BDE17, BDE28, BDE35, BDE37, BDE47, BDE49, BDE71, BDE75, BDE85, BDE99, BDE100, BDE119, BDE153 and BDE154). 
$\Sigma$ BDE concentrations ranged from 45 to $1,500 \mu \mathrm{gg}^{-1}$ lipid weight, with a geometric mean of $290 \mu \mathrm{g} \mathrm{kg}^{-1}$ lipid weight. BDE47 dominated the congener profile, followed by BDE100, BDE99, BDE153 and BDE154. No significant differences were found between males and females, probably due to the young age of the animals. A significant decrease was observed in $\Sigma$ BDE concentrations between newly weaned seals in 1998 and 1999 (p < 0.01), but not for the majority of juveniles in 1999 and 2000.

In a recent study, Thomas et al. (2004) conducted an input-output balance study of BDEs on three captive, juvenile grey seals. The animals were fed a diet of herring for six months, and the study was performed during the last 3 months of this period. BDE analysis was undertaken using GC-ECNIMS. A supplement of BDE209 (not present at detectable concentrations in the fish) was included in the diet during the second month of the study. Consistently high absorption (89 - 99\%) was observed for all BDE congeners studied (BDE28, BDE47, BDE49, BDE99, BDE100, BDE153, BDE154 and BDE209), in contrast to earlier studies which have shown very low absorption of BDE209 in other animals. Measurable concentrations of BDE209 were found in seal blubber at the end of the study, indicating that this compound can be stored in blubber and may accumulate, although it is difficult to assess whether this is of environmental significance as this is not a route by which wild seals (or other marine mammals) are currently exposed.

\section{Discussion and Conclusions}

Following the cessation of use of the penta-mix PBDE formulation in Europe, concentrations of BDE congeners derived from that product rapidly began to fall in human milk samples from Sweden (Meironyté and Norén, 2001), although it is not known whether similar decreases are also occurring in other European countries at the same rate. It should also be noted that this may not prove to be the case in either other environmental compartments or for all congeners, as, for fish and possibly other biota, direct exposure to commercial formulations may not be the only source of exposure and/or uptake. Laboratory experiments have shown debromination of BDE209 fed to carp (Cyprinus carpio) following dietary exposure using spiked food pellets. Stapleton et al. (2004b) demonstrated that, although BDE209 did not accumulate in carp tissue in their experiment, at least seven penta- to octa-brominated congeners were formed during the 60 days of exposure, including BDE153 and BDE154. These two congeners are commonly found in fish tissues and are usually ascribed to exposure to the penta-mix PBDE formulation. For this to occur in wild fish, they would need to be exposed to BDE209 contaminated prey, via uptake from sediment into e.g. benthic invertebrates. In addition, significant debromination of BDE99 and BDE183 in the intestinal tract of carp has been reported (Stapleton et al., 2004a), converting BDE99 to BDE47, and BDE183 to BDE154 and another (as yet unidentified) hexa-BDE congener. During the experiments, ca. 10\% of BDE99 and ca. 17\% of BDE183 were debrominated and the products assimilated in carp tissues. Similar debromination has also been reported in eels in the study by Allchin and Morris (2003), bream (P.E.G. Leonards, personal communication) and large-scale suckers (Catostomus macrocheilus), another fish species (Johnson and Olson, 2001). In a 
further study, Tomy et al. (2004) suggested the debromination of BDE 209 as the source of BDE140 accumulated in fish tissue during feeding experiments with lake trout (Salvelinus namaycush), on the basis of its substitution pattern.

There is still a concern that BDE209 may debrominate in the wider environment to form less-brominated BDE congeners which are more bioavailable than BDE209 itself. Söderström et al. (2004) studied the photolytic debromination of BDE209 both in the laboratory under UV-light (natural and artificial matrices) and under natural conditions with outdoor sunlight (sand, soil and sediment). BDE209 was photolytically labile, and formed debromination products in all matrices and under both UV-light and in sunlight. The BDEs formed were tetra- to nona-congeners, and the rates of debromination were slower on the natural matrices. Rosa et al. (2003) and Zetzsch et al. (2004) have studied the photochemistry of both BDE209 and BDE153. They noted that the debromination pathways via nona-, octa- and hepta-BDE congeners of BDE209 may produce a congener pattern different to that of the commercial penta-mix and octa-mix PBDE formulations, and that pholysis of BDE153 yielded a variety of di- to penta-BDE congeners. The environmental significance of this process is, as yet, unknown.

The reporting of the occurrence of BDE209 in aquatic biota is of great interest, not least as an input to ongoing risk assessments of the continued use of brominated flame retardant products. There are relatively few authenticated reports of the occurrence of BDE209 in biota that form part of an aquatic food web (Kierkegaard et al., 1999; Lepom et al., 2002; Voorspoels et al., 2003), although there is a growing body of evidence that suggests that BDE209 is bioavailable to a number of bird species with a terrestrial food source. BDE209 has also been shown to cross the gut wall of trout in laboratory experiments (Kierkegaard et al., 1999; Tomy et al., 2004), although the biomagnification factor for BDE209 is < 1. It is clear, though, that BDE209 will only be found in tissues of fish in which debromination of the compound either does not occur, or does so slowly, and future studies of BDE uptake will need to identify and target such species. Samples should also be taken from areas where BDE209 concentrations are high in the sediments. The determination of BDE209 is not straightforward and results from international intercomparison exercises and laboratory proficiency schemes suggest that in most laboratories the determination of BDE209 is still not under control, and that interlaboratory variability can be considerable (de Boer and Wells, 2004). Suitable methodologies do exist, however, and need to be more widely applied.

A feature of this review has been the wide application of chromatographic and mass spectral techniques, a number of which have deviated from the ideal considering the properties of the compounds determined. With a general lack of available reference materials certified for these compounds, the onus is on individual analysts to assess their analytical quality control procedures and, where possible, to have a number of samples analysed in other experienced laboratories as a cross-check of data quality. 
The determination of HBCD on an individual diastereomer basis by LC-MS is now a fully established method (Budakowski and Tomy, 2003; Morris et al., 2003; Tomy et al., 2003). Whilst it is accepted that not all laboratories have access to LC-MS, it is the preferred technique and offers many benefits over the determination of HBCD as total HCBD by GC-MS without diastereomer resolution and with the additional GC-associated problems caused by the thermal instability of HBCD (Eljarrat et al., 2004b). As indicated by Hites (2004b) when reviewing environmental information concerning the BDEs, there is no substitute for good-quality, congener-specific data if sources (and transformation and fate) are to be elucidated, and a diastereomer-specific approach to the determination of HBCD is recommended. It is also evident that very few laboratories are reporting data for HBCD or TBBP-A in even the most recent intercomparison studies (de Boer and Wells, 2004). More attention should be paid in future studies to TBBP-A as it is a high-volume BFR compound (see Table 1) and it seems, from recent studies, that it may exhibit more toxicity than less polar BFRs such as HBCD and the BDEs.

The study by Hites et al. (2004a) of BDEs in farmed and wild salmon has served to highlight the dilemma surrounding the consumption of fatty fish. On one hand, the health benefits of the omega- 3 fatty acids contained in these fish are clear. On the other hand, consumption of (especially) farmed salmon exposes consumers to higher burdens of BDEs and other lipophilic contaminants (such as dioxins, furans and chlorobiphenyls) with an associated (though, for the BDEs, poorly understood) health risk. The development of less contaminated feed for the farmed salmon could be one way of reducing contaminant levels, along with sourcing fish from less contaminated areas.

There is a need for an internationally agreed minimum common congener set for use when determining BDEs, similar to the ICES7 CB list, as an aid to comparison across studies. Although most laboratories use a similar suite of penta-mix related congeners a number use extended sets and where the data is presented as summary data only this can lead to problems with interpretation. As a suggestion, and to cover all three commercial PBDE formulations, maybe such an agreed set could comprise: BDE28, BDE47, BDE99, BDE100, BDE153, BDE154, BDE183 and BDE209, to be supplemented by additional congeners in line with the aims of the specific study.

In a recent study, a novel brominated flame retardant compound, decabromodiphenyl ethane (DeBDethane) was positively identified using high-resolution mass spectrometry and was quantified using low-resolution mass spectrometry in the electron capture negative ionisation MS mode in sewage sludge, sediment and indoor air (Kierkegaard et al., 2004b). This compound is marketed as an alternative to the deca-mix PBDE formulation. Its applications are the same as for the deca-mix, i.e. as an additive flame retardant in different types of plastics and textiles. DeBDethane was detected in sewage sludge from 25 of the 50 Swedish sewage treatment plants investigated, at estimated concentrations up to $100 \mu \mathrm{gg}^{-1}$ dry weight. DeBDethane was also detected in sediment from the Western Scheldt in the Netherlands, which was collected in 2001 from an area highly contaminated with BDE209 (de Boer et al., 2003), at an estimated concentration of 
$24 \mu \mathrm{gg}^{-1}$ dry weight. An air sample collected from a Swedish electronics dismantling facility (Tollbäck et al., 2003) contained $0.6 \mathrm{ng} \mathrm{m}^{-3}$, and DeBDethane was also found, together with nonabromodiphenyl ethanes, in the insulation for water pipes. All samples contained BDE209 at higher concentrations than DeBDethane (DeBDethane/BDE209 ratios ranged from 0.02 to 0.7 ), probably reflecting the higher volume and longer-term usage of BDE209. Additional studies are needed across a wider geographical area in order to establish the environmental significance of this compound. It is also essential that future environmental studies include the determination of the range of brominated flame retardants that are being, or have been, used in Europe (a minimum of the penta-mix, octamix and deca-mix PBDE formulations, HBCD and TBBP-A) in order to establish trends in their distribution resulting from changes in their patterns of use and the effectiveness of controls on the production and use of some products. Study of MeO-BDEs and other naturally occurring brominated compounds are also encouraged, so as to obtain a fuller characterisation of Br-containing compounds in the environment and to assist in the elucidation of metabolic pathways for BDEs

The number of studies cited in this paper which have been published since the reviews of 2002 and 2003 (over 70 cited papers and reports published, or in press, for 2003 and the first nine months of 2004) highlights the continuing interest and high level of activity in research on the environmental distribution, fate, transport and effects of brominated flame retardants (and especially the brominated diphenyl ethers) in Europe. Most recently, there has been a call for the polybrominated diphenyl ethers to be added to the list of compounds to be controlled under the Stockholm Convention on Persistent Organic Pollutants (Tanabe, 2004).

\section{Acknowledgement}

Funding for CEFAS involvement in the UK National Marine Monitoring Programme, which now includes studies of brominated flame retardants in sediments and fish (dab) liver around the UK coast, is provided by the Department for Environment, Food and Rural Affairs.

\section{References}

Agrell, C., ter Schure, A.F.H., Sveder, J., Bokenstrand, A., Larsson, P., Zegers, B.N., 2004. Polybrominated diphenyl ethers (PBDEs) at a solid waste incineration plant I: atmospheric concentrations. Atmos. Environ. 38, 5139-5148.

Alcock, R.E., Sweetman, A.J., Prevedouros, K., Jones, K.C., 2003. Understanding levels and trends of BDE-47 in the UK and North America: an assessment of principal reservoirs and source inputs. Environ. Int. 29, 691-698.

Allchin, C.R., de Boer, J., 2001. Results of a comprehensive survey for PBDEs in the River Tees, UK. Organohal. Cpds. 52, 30-34. 
Allchin, C.R., Law, R.J., Morris, S., 1999. Polybrominated diphenylethers in sediments and biota downstream of potential sources in the UK. Environ. Pollut. 105, 197-207.

Allchin, C.R., Morris, S., 2003. Hexabromocyclododecane (HBCD) diastereoisomers and brominated diphenyl ether congener (BDE) residues in edible fish from the Rivers Skerne and Tees, UK. Organohal. Cpds. 61, 41-44.

Asplund, L., Bignert, A., Nylund, K., 2004. Comparison of spatial and temporal trends of methoxylated PBDEs, PBDEs, and hexabromocyclododecane in herring along the Swedish coast. Organohal. Cpds. 66, 3988-3992.

Bethune, C., Nielsen, J., Julshamn, K., 2004. Current levels of primary polybrominated diphenyl ethers (PBDEs) in Norwegian seafood. Organohal. Cpds. 66, 3861-3866.

de Boer, J., 1989. Organochlorine compounds and bromodiphenylethers in livers of Atlantic cod (Gadus morhua) from the North Sea, 1977-1987. Chemosphere 18, 21312140.

de Boer, J., Allchin, C.R., 2001. An indication of temporal trends in environmental PBDE levels in Europe. Organohal. Cpds. 52, 12-17.

de Boer, J., Allchin, C., Zegers, B., Boon, J.P., Brandsma, S.H., Morris, S., Kruijt, A.W., van der Veen, I., van Hesselingen, J.M., Haftka, J.J.H., 2002. HBCD and TBBP-A in sewage sludge, sediments and biota, including interlaboratory study, RIVO rapport number C033/02, September 2002, 40 pp + annexes.

de Boer, J., Leslie, L.A., Leonards, P.E.G., Bersuder, P., Morris, S., Allchin, C.R., 2004. Screening and time trend study of decabromodiphenylether and hexabromocyclododecane in birds. Proceedings of the Third International Workshop on Brominated Flame Retardants BFR2004, Toronto, Canada, June 6-9, 2004. pp. 125-128.

de Boer, J., Wells, D., 2004. The third international interlaboratory study on brominated flame retardants. Organohal. Cpds. 66: 510-518.

de Boer, J., Wester, P.G., van der Horst, A., Leonards, P.E.G., 2003. Polybrominated diphenyl ethers in influents, suspended particulate matter, sediments, sewage treatment plant and effluents and biota from the Netherlands. Environ. Pollut. 122, 63-74.

Booij, K., Zegers, B.N., Boon, J.P., 2002. Levels of some polybrominated diphenyl ether (PBDE) flame retardants along the Dutch coast as derived from their accumulation in SPMDs and blue mussels (Mytilus edulis). Chemosphere 46, 683-688. 
Boon, J.P., Lewis, W.E., Tjoen-a-Choy, M.R., Allchin, C.R., Law, R.J., de Boer, J., ten Hallers-Tjabbes, C.C., Zegers, B.N., 2002. Levels of polybrominated diphenyl ether (PBDE) flame retardants in animals representing different trophic levels of the North Sea food web. Environ. Sci. Technol. 36, 4025-4032.

Boon, J.P., van der Meer, J., Allchin, C.R., Law, R.J., Klungsøyr, J., Leonards, P.E.G., Spliid, H., Storr-Hansen, E., McKenzie, C., Wells, D.E., 1997. Concentration-dependent changes of PCB patterns in fish-eating mammals: structural evidence for induction of cytochrome P450. Arch. Environ. Contam. Toxicol. 33, 298-311.

Broman, D., Balk, L., Zebühr, Y., Warman, K., 2001. Miljöövervakning i Stockholms kommun, Saltsjön och Mälaren - Kemi. Slutrapport: provtagningsår 96/97, 97/98 och 98/99. Institute of Applied Environmental Research (ITM), Stockholm University, Stockholm, Sweden (in Swedish).

Budakowski, W., Tomy, G., 2003. Congener-specific analysis of hexabromocyclododecane by high-performance liquid chromatography/electrospray tandem mass spectrometry. Rapid Commun. Mass Spectrom. 17, 1399-1404.

Burreau, S. 2001. On the uptake and biomagnification of PCBs and PBDEs in fish and aquatic food chains. Ph.D. dissertation, Stockholm University, Stockholm, Sweden.

Burreau, S., Zebühr, Y., Broman, D., Ishaq, R, 2004. Biomagnification of polychlorinated biphenyls (PCBs) and polybrominated diphenyl ethers (PBDEs) studies in pike (Esox lucius), perch (Perca fluviatilis) and roach (Rutilus rutilus) from the Baltic Sea. Chemosphere 55, 1043-1052.

Bytingsvik, J., Gaustad, H., Salmer, M.P., Soermo, E.G., Baek, K., Føreid, S., Ruus, A., Skaare, J.U., Jenssen, B.M., 2004. Spatial and temporal trends of BFRs in Atlantic cod and Polar cod in the North-East Atlantic. Organohal. Cpds. 66, 3918-3922.

de la Cal, A., Eljarrat, E., Barceló, D., 2003. Determination of 39 polybrominated diphenyl ether congeners in sediment samples using fast selective pressurized liquid extraction and purification. J. Chromatog. A. 1021, 165-173.

Christensen, J.H., Groth, B.S., Vikelsøe, J., Vorkamp, K., 2003. Polybrominated diphenyl ethers (PBDEs) in sewage sludge and wastewater, NERI technical report no 481, December 2003, 28pp.

Covaci, A., Gheorghe, A., Hulea, O., Schepens, P., 2002b. Levels of organohalogenated pollutants (PCBs, OCPs and PBDEs) in biota from the Danube delta, Romania. Organohal. Cpds. 59, 9-12. 
Covaci, A., Gheorghe, A., Steen Redeker, E., Blust, R., Schepens, P., 2002a. Distribution of organochlorine and organobromine pollutants in two sediment cores from the Scheldt estuary (Belgium). Organohal. Cpds. 57, 239-242.

Covaci, A., Bervoets, L., Hoff, P., Voorspoels, S., Voets, J., Van Campenhout, K., Blust, R., Schepens, P., 2004. PBDEs in freshwater mussels and fish from Flanders, Belgium. Organohal. Cpds. 66: 3848-3855.

Covaci, A., Van de Vijver, K., DeCoen, W., Das, K., Bouqeugneau, J.M., Blust, R., Schepens, P., 2002c. Determination of organohalogenated contaminants in liver of harbour porpoises (Phocoena phocoena) stranded on the Belgian North Sea coast. Mar. Pollut. Bull. 44, 1157-1165.

Dodder, N.G., Strandberg, B., Hites, R.A., 2002. Concentrations and spatial variations of polybrominated diphenmyl ethers and several organochlorine compounds in fishes from the Northeastern United States. Environ. Sci. Technol. 36, 146-151.

D’Silva, K., Thompson, H., Fernandes, A., Duff, M., 2004. PBDEs in heron adipose tissue and eggs from the United Kingdom. Proceedings of the Third International Workshop on Brominated Flame Retardants BFR2004, Toronto, Canada, June 6-9, 2004. pp. 195-198.

Eljarrat, E., de la Cal, A., Barceló, D., 2004a. Determination of decabromodiphenyl ether in sediments using pressurized liquid extraction followed by GC-NCI-MS. Anal. Bioanal. Chem. 378, 610-614.

Eljarrat, E., de la Cal, A., Raldua, D., Duran, C., Barceló, D, 2004b. Occurrence and bioavailability of polybrominated diphenyl ethers and hexabromocyclododecane in sediment and fish from the Cinca River, a tributary of the Ebro River (Spain). Environ. Sci. Technol. 38, 2603-2608.

Eljarrat, E., de la Cal, A., Raldua, D., Duran, C., Barceló, D, 2004c. Brominated flame retardants in Alburnus alburnus from Cinca River Basin (Spain). Environ. Pollut. In press.

Fabrellas, B., Larrazabal, D., Martinez, M.A., Eljarrat, E., Barceló, D, 2004. Presence of polybrominated diphenyl ethers in Spanish sewage sludges: important contribution of deca-BDE. Organohal. Cpds. 66, 3755-3760.

Farrar, N.J., Smith, K.E.C., Lee, R.G.M., Thomas, G.O., Sweetman, A.J., Jones, K.C., 2004. Atmospheric emissions of polybrominated diphenyl ethers and other persistent organic pollutants during a major anthropogenic combustion event. Environ. Sci.

Technol. 38, 1681-1685. 
Gama, A.C., Sanatcumar, P., Viana, P., Barceló, D., Bordado, J.C., 2004. The occurrence of polybrominated diphenyl ethers (PBDEs) in river and coastal biota from Portugal. Proceedings of the Third International Workshop on Brominated Flame Retardants BFR2004, Toronto, Canada, June 6-9, 2004. pp. 191-194.

Gerecke, A.C., Kohler, M., Zennegg, M., Schmid, P., Heeb, N.V., 2003. Detection of $\alpha-$ isomer dominated HBCD (hexabromocyclododecane) in Swiss fish at levels comparable to PBDEs (polybrominated diphenyl ethers). Organohal. Cpds. 61, 155-158.

Gribble, G.W., 2000. The natural production of organobromine compounds. Environ. Sci. Pollut. Res., 7, 37-49.

Götsch, A., Mariussen, E., von der Recke, R., Herzke, D., Vetter, W. and Berger, U., 2004. Enantioselective separation of atropisomeric PBB132 and PBB149 in extracts from a Norwegian white-tailed sea eagle egg. Proceedings of the Third International Workshop on Brominated Flame Retardants BFR2004, Toronto, Canada, June 6-9 2004. pp. 351354.

Gustafsson, K., Björk, M., Burreau, S., Gilek, M., 1999. Bioaccumulation kinetics of brominated flame retardants (polybrominated diphenyl ethers) in blue mussels (Mytilus edulis). Environ. Toxicol. Chem. 18, 1218-1224.

Haglund, P.S., Zook, D.R., Buser, H.-R., Hu, J., 1997. Identification and quantitation of polybrominated diphenyl ethers and methoxy- polybrominated diphenyl ethers in Baltic biota. Environ. Sci. Technol. 31, 3281-3287.

Hall, A.J., Kalantzi, O.I., Thomas, G.O., 2003. Polybrominated diphenyl ethers (PBDEs) in grey seals during their first year of life - are they thyroid hormone endocrine disrupters ?. Environ. Pollut. 126, 29-37.

Harrad, S., Hunter, S., 2004. Spatial variation in atmospheric levels of PBDEs in passive air samples on an urban-rural transect. Organohal. Cpds. 66, 3786-3792.

Harrad, S., Wijesekera, R., Hunter, S., Halliwell, C., Baker, R., 2004. Preliminary assesment of UK human dietary exposure to polybrominated diphenyl ethers. Environ. Sci. Technol. 38, 2345-2350.

Hassanin, A., Breivik, K., Meijer, S.N., Steinnes, E., Thomas, G.O., Jones, K.C., 2004. PBDEs in European background soils: levels and factors controlling their distribution. Environ. Sci. Technol. 38, 738-745.

Herzke, D., Berger, U., Kallenborn, R., Nygård, T., Vetter, W., in press 2005. Brominated flame retardants and other organobromines in Norwegian predatory bird eggs. Chemosphere 
Herzke, D., Evenset, A., Christensen, G.N., Kallenborn, R., 2004. Polybrominated diphenylethers in biota from Bjørnøya (Bear Island). Proceedings of the Third International Workshop on Brominated Flame Retardants BFR2004, Toronto, Canada, June 6-9, 2004. pp. 199-202.

Herzke, D., Gabrielsen, G.W., Evenset, A., Burkow, I.C., 2003. Polychlorinated camphenes (toxaphenes), polybrominated diphenylethers and other halogenated organic pollutants in glaucous gull (Larus hyperboreus) from Svalbard and Bjørnøya (Bear Island). Environ. Pollut. 121, 293-300.

Herzke, D., Kallenborn, R., Nygård, T., Sandanger, T., 2001. Species dependent distribution of polybrominated biphenyls and diphenylethers in eggs of Norwegian birds of prey. Proceedings of the second international workshop on brominated flame retardants BFR2001, Stockholm, Sweden, May 14-16, 2001, pp. 321-324.

Hites, R.A., 2004b. Polybrominated diphenyl ethers in the environment and in people: a meta-analysis of concentrations. Environ. Sci. Technol. 38, 945-956.

Hites, R.A., Foran, J.A., Schwager, S.J., Knuth, B.A., Hamilton, M.C., Carpenter, D.O., 2004a. Global assessment of polybrominated diphenyl ethers in farmed and wild salmon. Environ. Sci. Technol. 38: 4945-4949.

Jacobs, M.N., Covaci, A., Schepens, P., 2002. Investigation of selected persistent organic pollutants in farmed Atlantic salmon (Salmo salar), salmon aquaculture feed and fish oil components of the feed. Environ. Sci. Technol. 36, 2797-2805.

Janak, K., Thomsen, C., Becher, G., 2004. Enantiomer specific determination of HBCD diastereomers by LC-MS-MS. Proceedings of the Third International Workshop on Brominated Flame Retardants BFR2004, Toronto, Canada, June 6-9, 2004. pp. 313-316.

Jaspers, V., Covaci, A., Maervoet, J., Dauwe, T., Schepens, P., Eens, M., 2004.

Brominated flame retardants in Belgian little owl (Athene noctua) eggs. Organohal. Cpds. 66, 3856-3860.

Jaward, F.M., Farrar, N.J., Harner, T., Sweetman, A.J., Jones, K.C., 2004a. Passive air sampling of PCBs, PBDEs, and organochlorine pesticides across Europe. Environ. Sci. Technol. 38, 34-41.

Jaward, F.M., Meijer, S.N., Steinnes, E., Thomas, G.O., Jones, K.C., 2004b. Further studies on the latitudinal and temporal trends of persistent organic pollutants in Norwegian and UK background air. Environ. Sci. Technol. 38, 2523-2530. 
Johansson, I., Héas-Moisan, K., Guiot, N., Munschy, C., Tronczynski, J., in press 2005. Polybrominated diphenyl ethers (PBDEs) in mussels over the past twenty years at selected sites of the French coast. Chemosphere,

Johansson, I., Moisan, K., Guiot, N., Truquet, I., Munschy, C., Tronczynski, J., 2004. Levels and trends of organohalogen compounds in mussels from the Seine estuary in 1981-2003. Organohal. Cpds. 66, 1844-1852.

Johnson, A., Olson, N., 2001. Analysis and occurrence of polybrominated diphenyl ethers in Washington State freshwater fish. Arch. Environ. Contam. Toxicol. 41, 339-344.

Kalantzi, O.I., Hall, A.J., Thomas, G.O., Jones, K.C., 2004. Polybrominated diphenyl ethers and selected organochlorine chemicals in grey seals (Halichoerus grypus) in the North Sea. Chemosphere in press.

Kierkegaard, A., Balk, L., Tjärnlund, U., de Wit, C., Jansson, B., 1999. Dietary uptake and biological effects of decabromodiphenyl ether in rainbow trout (Onchorhyncus mykiss). Environ. Sci. Technol. 33, 1612-1617.

Kierkegaard, A., Bignert, A., Sellström, U., Olsson, M., Asplund, L., Jansson, B., de Wit, C.A., 2004a. Polybrominated diphenyl ethers (PBDEs) and their methoxylated derivatives in pike from Swedish waters with emphasis on temporal trends, 1967-2000. Environ. Pollut. 130, 187-198.

Kierkegaard, A., Björklund, J., Fridén, U., 2004b. Identification of the flame retardant decabromodiphenyl ethane in the environment. Environ. Sci. Technol. 38, 3247-3253.

Kilemade, M., Hartl, M.G.J., Sheehan, D., Mothersill, C., van Pelt, F.N.A.M., O’Brien, N.M., O’Halloran, J., 2004. An assessment of the pollutant status of surficial sediment in Cork Harbour in the South East of Ireland with particular reference to polycyclic aromatic hydrocarbons. Mar. Pollut. Bull., 49, 1084-1096.

Lacorte, S., Guillamón, M., Martínez, E., Viana, P., Barceló, D., 2003. Occurrence and specific congener profile of 40 polybrominated diphenyl ethers in river and coastal sediments from Portugal. Environ. Sci. Technol. 37, 892-898.

Law, R.J., Alaee, M., Allchin, C., Boon, J.P., Lebeuf, M., Lepom, P., Stern, G.A,. 2003. Levels and trends of polybrominated diphenylethers and other brominated flame retardants in wildlife. Environ. Int. 29, 757-770.

Law, R.J., Allchin, C.R., Bennett, M.E., Morris, S., Rogan, E., 2002. Polybrominated diphenyl ethers in two species of marine top predators from England and Wales.

Chemosphere 46, 673-681. 
Lee, R.G.M., Thomas, G.O., Jones, K.C., 2004. PBDEs in the atmosphere of three locations in Western Europe. Environ. Sci. Technol. 38, 699-706.

Leonards, P., Vethaak, D., Brandsma, S., Kwadijk, C., Micic, D., Jol, J., Schout, P., de Boer, J., 2004. Species specific accumulation and biotransformation of polybrominated diphenyl ethers and hexabromocyclododecane in two Dutch food chains. Proceedings of the Third International Workshop on Brominated Flame Retardants BFR2004, Toronto, Canada, June 6-9 2004. pp. 283-286.

Lepom, P., Karasyova, T., Sawal, G., 2002. Occurrence of PBDEs in freshwater fish from Germany. Organohal. Cpds. 58: 209-212.

Lindberg, P., Sellström, U., Häggberg, L., de Wit, C.A., 2004. Higher brominated diphenyl ethers and hexabromocyclododecane found in eggs of peregrine falcons (Falco peregrinus) breeding in Sweden. Environ. Sci. Technol. 38, 93-96.

Lithner, G., Holm, K., Ekström, C., 2003. Metaller och organiska miljögifter i vattenlevande organismer och deras miljö i Stockholm 2001. ITM Rapport 108, 87 pp., Institute of Applied Environmental Research (ITM), Stockholm University, Stockholm, Sweden, ISBN 91-631-3758-5 (in Swedish).

Magnusson, K., Agrenius, S., Ekelund, R., 2003. Distribution of a tetrabrominated diphenyl ether and its metabolites in soft-bottom sediment and macrofauna species. Mar. Ecol. Prog. Ser. 255, 155-170.

Mariussen, E., Fjeld, E., Strand-Andersen, M., Hjerpset, M., Schlabach, M., 2003. Spatial distribution of polybrominated diphenyl ethers in trout from Norwegian lakes. Organohal. Cpds. 61, 69-72.

Marsh, G., Athanasiadou, M., Bergman, Å., Asplund, L., 2004. Identification of hydroxylated and methoxylated polybrominated diphenyl ethers in Baltic Sea salmon (Salmo salar) blood. Environ. Sci. Technol. 38, 10-18.

Matscheko, N., Tysklind, M, de Wit, C., Bergek, S., Andersson, R., Sellström, U., 2002. Application of sewage sludge to arable land - soil concentrations of polybrominated diphenyl ethers and polychlorinated dibenzo- $p$-dioxins, dibenzofurans, and biphenyls, and their accumulation in earthworms. Environ. Toxicol. Chem. 21, 2515-2525.

Meironyté, D., Norén, 2001. Polybrominated diphenyl ethers in Swedish human milk. The follow-up study. Proceedings of the Second International Workshop on Brominated Flame Retardants BFR2001, Stockholm, Sweden, May 14-16 2001, pp. 303-305.

Moche, W., Stephan, K., 2003. Levels of PBDE in various environmental matrices in Austria. Organohal. Cpds. 61, 147-150. 
Moche, W., Thanner, G., 2004. Levels of PBDE in effluents and sludge from sewage treatment plants in Austria. Proceedings of the Third International Workshop on Brominated Flame Retardants BFR2004, Toronto, Canada, June 6-9 2004. pp. 167-170.

Morris, S., Allchin, C.R., Bersuder, P., Zegers, B., Haftka, J.J.H., Boon, J.P., Brandsma, S.H., Kruijt, A.W., van der Veen, I., van Hesselingen, J., de Boer, J., 2003. A new LCMS method for the detection and quantification of hexabromocyclododecane diastereoisomers and tetrabromobisphenol-A flame retardants in environmental samples. Organohal. Cpds. 60, 436-439.

Morris, S., Allchin, C.R., Zegers, B.N., Haftka, J.J.H., Boon, J.P., Belpaire, C., Leonards, P.G., van Leeuwen, S.P.J., de Boer, J., 2004. The distribution and fate of HBCD and TBBP-A brominated flame retardants in North Sea estuaries and aquatic food webs. Environ. Sci. Technol. 38, 5497-5504.

Paepke, O., Herrmann, T., 2004. Polybrominated diphenylethers (PBDEs) in fish samples of various origin. Organohal. Cpds. 66: 3971-3975.

Prevedouros, K., Jones, K.C., Sweetman, A.J., 2004. Estimation of the production, consumption, and atmospheric emissions of pentabrominated diphenyl ether in Europe between 1970 and 2000. Environ. Sci. Technol. 38, 3224-3231.

Remberger, M., Sternbeck, J., Palm, A., Kaj, L., Strömberg, K., Brorström-Lundén, E., 2004. The environmental occurence of hexabromocyclododecane in Sweden.

Chemosphere 54, 9-21.

Rosa, M.B.D., Krüger, H., Thomas, S., Zetzsch, C., 2003. Photolytic degradation of decabromodiphenyl ether, an exploratory kinetic study in toluene. Fresenius Environ. Bull. 12: 940-945.

Sawal, G., Stachel, B., Lepom, P., 2004. Polybrominated diphenyl ethers in sediments from the River Elbe, Germany. Proceedings of the Third International Workshop on Brominated Flame Retardants BFR2004, Toronto, Canada, June 6-9 2004. pp. 151-154.

Schlabach, M., Fjeld, E., Gundersen, H., Mariussen, E., Kjellberg, G., Breivik, E., 2004. Pollution of Lake Mjøsa by brominated flame retardants. Organohal. Cpds. 66: 37793785.

ter Schure, A.F.H., Agrell, C., Bokenstrand, A., Sveder, J., Larsson, P., Zegers, B.N., 2004b. Polybrominated diphenyl ethers at a solid waste incineration plant II: atmospheric deposition. Atmos. Environ. 38, 5149-5155. 
ter Schure, A.F.H., Larsson, P., 2002. Polybrominated diphenyl ethers in precipitation in Southern Sweden (Skåne, Lund). Atmos. Environ. 36, 4015-4022.

ter Schure, A.F.H., Larsson, P., Agrell, C., Boon, J.P., 2004a. Atmospheric transport of polybrominated diphenyl ethers and polychlorinated biphenyls to the Baltic Sea. Environ. Sci. Technol. 38, 1282-1287.

Sellström, U., Bignert, A., Kierkegaard, A., Häggberg, L., de Wit, C.A., Olsson, M., Jansson, B., 2003. Temporal trend studies on tetra- and pentabrominated diphenyl ethers and hexabromocyclododecane in guillemot egg from the Baltic Sea. Environ. Sci. Technol. 37, 5496-5501.

Sellström, U., Jansson, B., Kierkegaard, A, de Wit, C., Odsjö, T., Olsson, M., 1993. Polybrominated diphenyl ethers (PBDE) in biological samples from the Swedish environment. Chemosphere 26, 1703-1718.

Sellström, U., Kierkegaard, A., Alsberg, T., Jonsson, P., Wahlberg, C., de Wit, C., 1999. Brominated flame retardants in sediments from European estuaries, the Baltic Sea and in sewage sludge. Organohal. Cpds. 40, 383-386.

Sellström, U., Kierkegaard, A., de Wit, C., Jansson, B., 1998. Polybrominated diphenyl ethers and hexabromocyclododecane in sediment and fish from a Swedish river. Environ. Toxicol. Chem. 17, 1065-1072.

Sinkkonen, S., Rantalainen, A.-L., Paasivirta, J., Lahtiperä, M., 2004. Polybrominated methoxy diphenyl ethers (MeO-PBDEs) in fish and guillemot of Baltic, Atlantic and Arctic environments. Chemosphere 56, 767-775.

Söderström, G., Sellström, U., de Wit, C.A., Tyskling, M., 2004. Photolytic debromination of decabromodiphenyl ether (BDE 209). Environ. Sci. Technol. 38, 127132.

Stapleton, H.M., Alaee, M., Letcher, R.J., Baker, J.E., 2004b. Debromination of the flame retardant decabromodiphenyl ether by juvenile carp (Cyprinus carpio) following dietary exposure. Environ. Sci. Technol. 38, 112-119.

Stapleton, H.M., Letcher, R.J., Baker, J.E., 2004a. Debromination of polybrominated diphenyl ether congeners BDE 99 and BDE 183 in the intestinal tract of the common carp (Cyprinus carpio). Environ. Sci. Technol. 38, 1054-1061.

Tanabe, S., 2004. PBDEs, an emerging group of persistent pollutants. Mar. Pollut. Bull. 49, 369-370. 
Thomas, G.O., Moss, S.E.W., Asplund, L., Hall, A.J., in press 2004. Absorption of decabromodiphenyl ether and other organohalogen chemicals by grey seals (Halichoerus grypus). Environ. Pollut.

Thron, K.U., Bruhn, R., McLachlan, M.S., 2004. The influence of age, sex, bodycondition, and region on the levels of PBDEs and toxaphene in harbour porpoises from European waters. Fresenius Environ. Bull. 13, 146-155.

Tollbäck, P., Björklund, J., Östman, C., 2003. Large-volume programmed-temperature vaporiser injection for fast gas chromatography with electron capture and mass spectrometric detection of polybrominated diphenyl ethers. J. Chromatog. A. 991, 214253.

Tomy, G., Budakowski, W., Halldorson, T., Alaee, M., MacInnis, G., Marvin, C., 2003. Congener-specific analysis of hexabromocyclododecane (HBCDD) by high performance liquid chromatography electrospray tandem mass spectrometry. Organohal. Cpds. 60, 448-451.

Tomy, G.T., Palace, V.P., Halldorson, T., Braekevelt, E., Danell, R., Wautier, K., Evans, B., Brinkworth, L., Fisk, A.T., 2004. Bioaccumulation, biotransformation, and biochemical effects of brominated diphenyl ethers in juvenile Lake Trout (Salvelinus namaycush). Environ. Sci. Technol. 38, 1496-1504.

Vives, I., Grimalt, J.O., Lacorte, S., Guillamón, M., Barceló, D.,Rosseland, B.O., 2004. Polybromodiphenyl ether flame retardants in fish from lakes in European high mountains and Greenland. Environ. Sci. Technol. 38, 2338-2344.

Voorspoels, S., Covaci, A., Schepens, P., 2003. Polybrominated diphenyl ethers in marine species from the Belgian North Sea and the Western Scheldt estuary: levels, profiles and distribution. Environ. Sci. Technol. 37, 4348-4357.

Voorspoels, S., Covaci, A., Schepens, P., 2004a. PBDEs in sediments from a polluted area in Europe: The Belgian North Sea, the Western Scheldt Estuary and tributaries. Proceedings of the Third International Workshop on Brominated Flame Retardants BFR 2004, Toronto, Canada, June 6-9 2004. pp. 133-136.

Voorspoels, S., Covaci, A., Schepens, P., 2004b. Brominated flame retardants in birds of prey from Flanders, Belgium. Organohal. Cpds. 66: 3884-3891.

WHO (World Health Organisation), 1994. Environmental Health Criteria 162, Brominated Diphenyl Ethers.

de Wit, C., 2002. An overview of brominated flame retardants in the environment. Chemosphere 46, 583-624. 
Wolkers, H., van Bavel, B., Derocher, A.E., Wiig, Ø., Kovacs, K.M., Lydersen, C., Lindström, G., 2004. Congener-specific accumulation and food chain transfer of polybrominated diphenyl ethers in two Arctic food chains. Environ. Sci. Technol. 38, 1667-1674.

Zegers, B.N., Lewis, W.A., Booij, K., Smittenberg, R.H., Boer, W., de Boer, J., Boon, J.P., 2003. Levels of polybrominated diphenyl ether flame retardants in sediment cores from Western Europe. Environ. Sci. Technol. 37, 3803-3807.

Zennegg, M., Kohler, M., Gerecke, A.C., Schmid, P., 2003. Polybrominated diphenyl ethers in whitefish from Swiss lakes and farmed rainbow trout. Chemosphere 51, 545553.

Zetzsch, C., Palm, W.-U., Krüger, H.-U., 2004. Photochemistry of 2, 2', 4, 4', 5, 5’hexaBDE (BDE153) in THF and adsorbed on $\mathrm{SiO}_{2}$ : first observation of $\mathrm{OH}$ reactivity of BDEs on aerosol. Organohal. Cpds. 66: 2281-2287. 
Table 1. The usage of selected brominated flame retardants in different areas of the world in 2001.

\begin{tabular}{|c|c|c|c|c|c|c|}
\hline [tonnes] & America & Europe & Asia & $\begin{array}{c}\text { Rest of the } \\
\text { world }\end{array}$ & Total & $\begin{array}{c}\text { \% of total } \\
\text { world usage }\end{array}$ \\
\hline TBBP-A & 18,000 & 11,600 & 89,400 & 600 & 119,700 & 59 \\
\hline HBCD & 2,800 & 9,500 & 3,900 & 500 & 16,700 & 8 \\
\hline $\begin{array}{c}\text { Deca-mix PBDE } \\
\text { formulation }\end{array}$ & 24,500 & 7,600 & 23,000 & 1,050 & 56,100 & 27 \\
\hline $\begin{array}{c}\text { Octa-mix PBDE } \\
\text { formulation }\end{array}$ & 1,500 & 610 & 1,500 & 180 & 3,790 & 2 \\
\hline $\begin{array}{c}\text { Penta-mix PBDE } \\
\text { formulation }\end{array}$ & 7,100 & 150 & 150 & 100 & 7,500 & 4 \\
\hline \begin{tabular}{c} 
Total \\
\hline Total
\end{tabular} & 53,900 & 29,460 & 117,950 & 2,430 & 203,790 & \\
\hline
\end{tabular}


Table 2. The mean, standard deviation and range of concentrations ( $\mu \mathrm{g} \mathrm{kg}^{-1}$ dry weight) for each BFR compound determined in sludge from 50 Swedish sewage treatment plants in 2000 .

\begin{tabular}{|l|l|l|l|}
\hline Substance & Mean & Standard deviation & Range \\
\hline BDE47 & 49 & 22 & $7.0-100$ \\
\hline BDE99 & 60 & 29 & $8.1-150$ \\
\hline BDE100 & 11 & 4.8 & $1.5-22$ \\
\hline BDE153 & 6.1 & 3.3 & $0.8-18$ \\
\hline BDE154 & 4.1 & 2.1 & $0.6-10$ \\
\hline IBDE & 130 & 60 & $18-260$ \\
\hline BDE209 & 120 & 160 & $5.6-1000$ \\
\hline HBCD & 45 & 94 & $3.8-650$ \\
\hline TBBP-A & 40 & 33 & $<4-180$ \\
\hline BB209 & 5.6 & 3.1 & $<0.4-10$ \\
\hline
\end{tabular}


Figure 1. Concentrations ( $\mu \mathrm{g} \mathrm{kg}^{-1}$ lipid weight, mean $\pm \mathrm{SE}$ ) of BDE47, BDE99, BDE100, BDE153, BDE154, BDE183, BDE209, BB153 and HBCD in eggs from two wild and one captive population of peregrine falcons in Sweden (Lindberg et al., 2004).

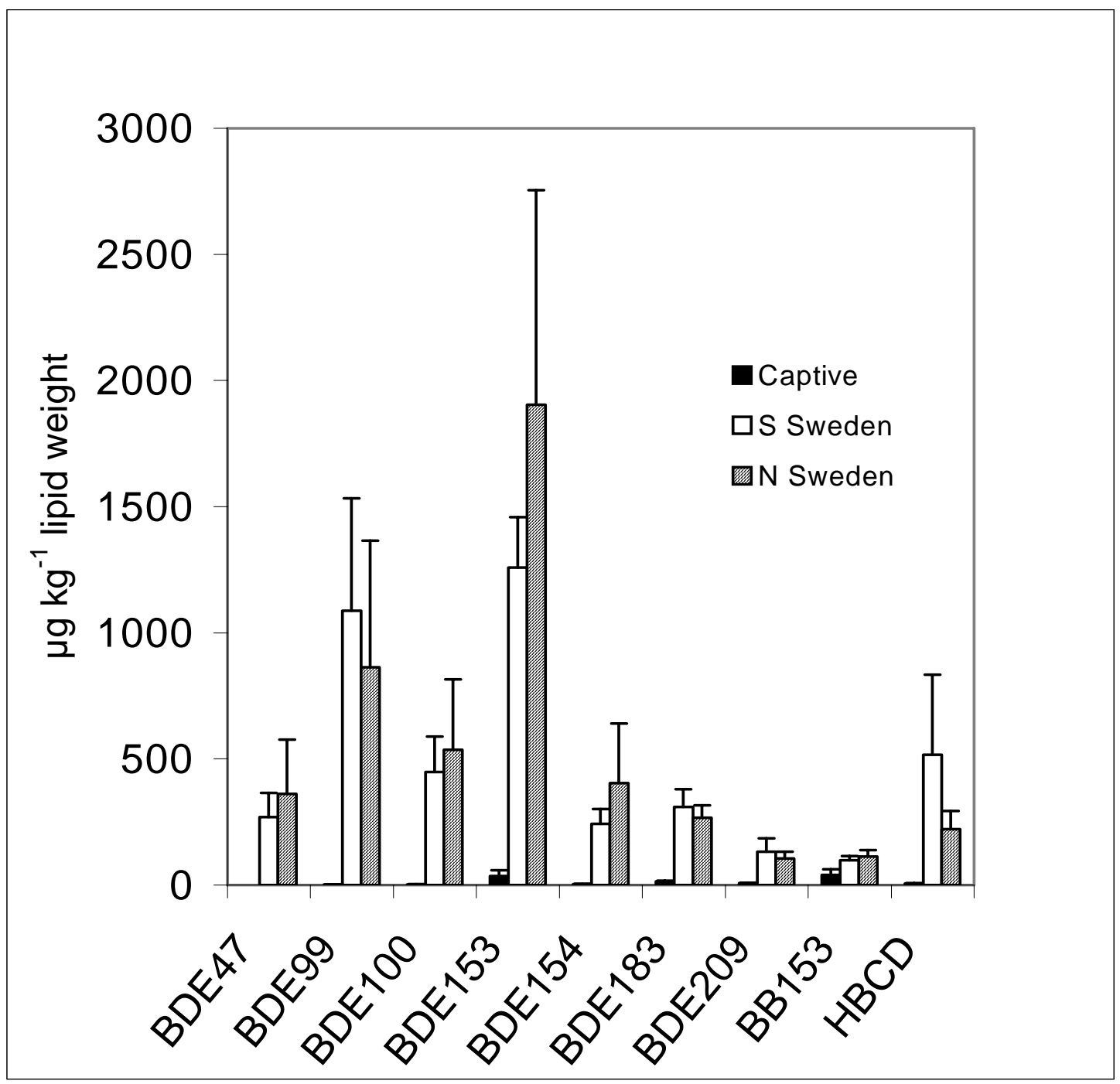




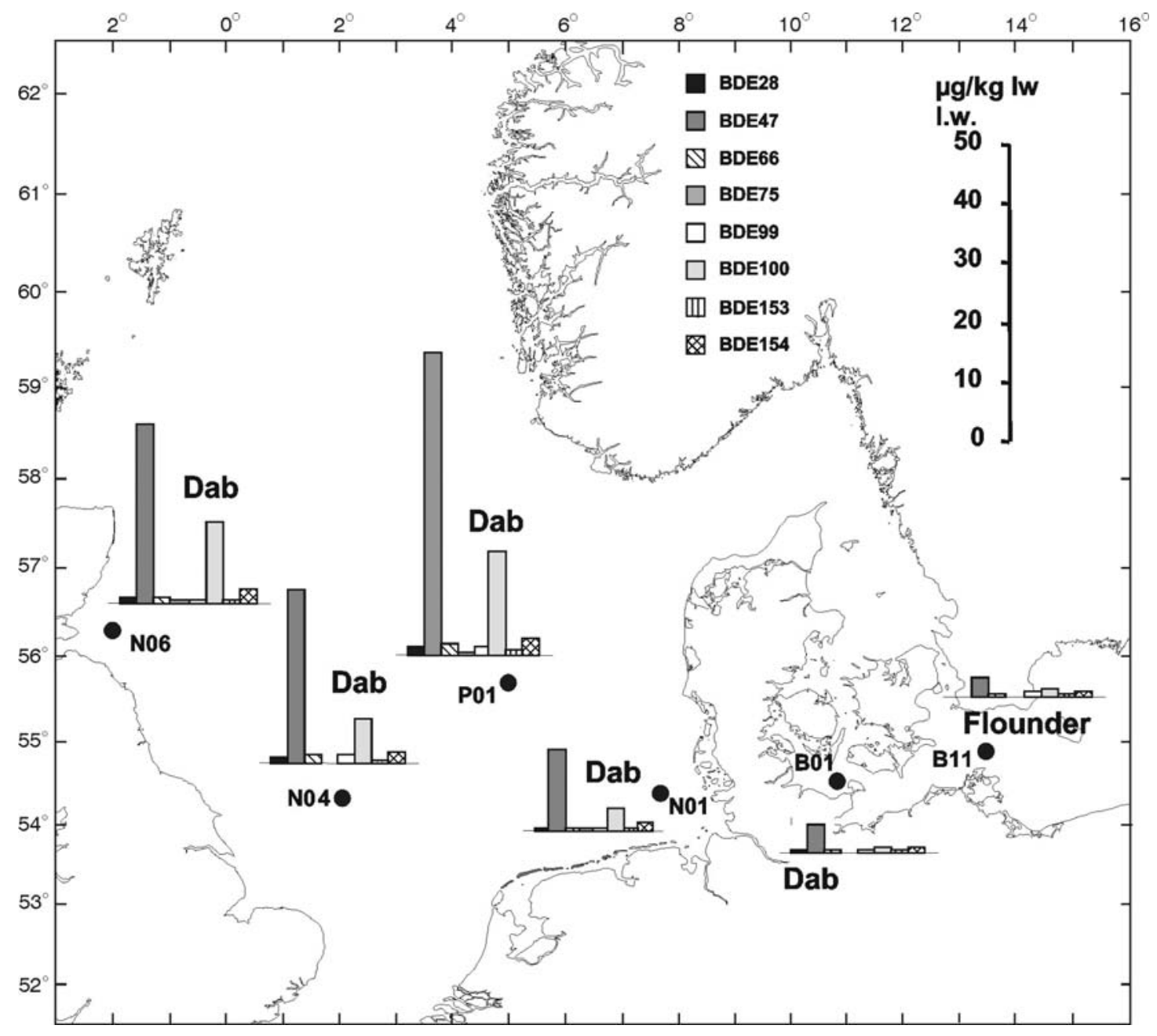

Figure 2. BDEs in liver of dab and flounder collected from six sampling sites in the North and the Baltic Seas between 25 August and 3 September 2002. Mean BDE concentrations

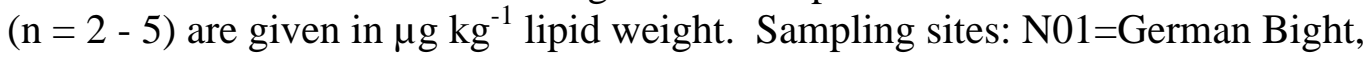
N04=Northern Dogger Bank, N06=Outer Firth of Forth, P01= Danfield, oil and gas production area, B01= Kiel Bight, B11=Central Baltic, north of Ruegen Island. 


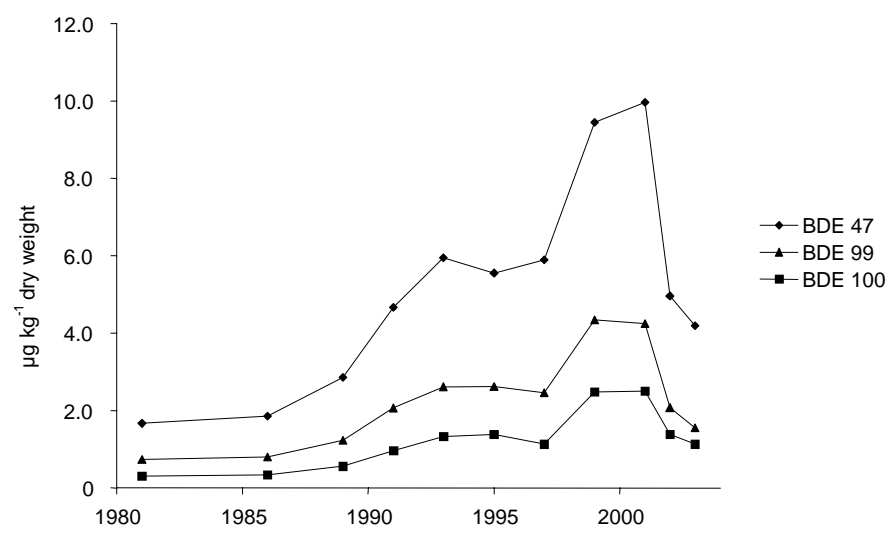

Figure 3. Concentrations of three brominated diphenyl ether congeners in mussels from Villerville at the mouth of the Seine estuary, France, sampled between 1981 and 2003 ( $\mu \mathrm{g}$ $\mathrm{kg}^{-1}$ dry weight). 